\title{
GROWTH
}

STRATEGIES AND

\section{VALUE CREATION}

\section{WHAT WORKS}

BEST FOR STOCK

\section{EXCHANGES?}

by Iftekhar Hasan,

Heiko Schmiedel and Liang Song 


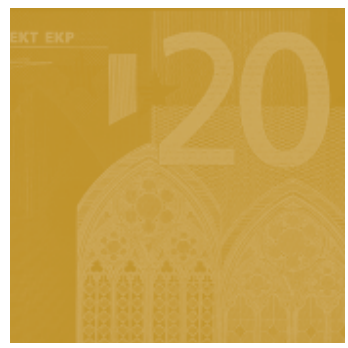

\title{
WORKING PAPER SERIES
}

NO I2OI I JUNE $20 I 0$

GROWTH STRATEGIES

AND VALUE CREATION

WHAT WORKS BEST FOR STOCK

EXCHANGES?'

\author{
by Iftekhar Hasan ${ }^{2}$, Heiko Schmiedel ${ }^{3}$ \\ and Liang Song ${ }^{4}$
}

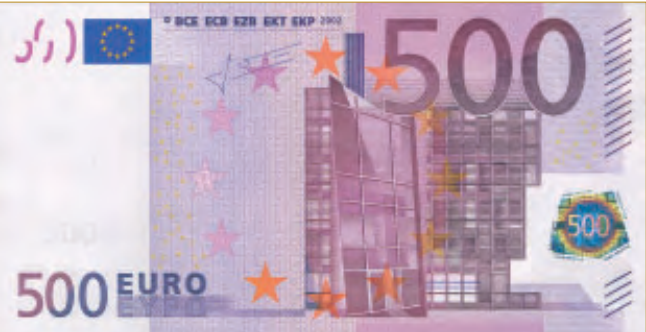

In 2010 all ECB

publication

feature a motif

taken from the

$€ 500$ banknote.

NOTE: This Working Paper should not be reported as representing the views of the European Central Bank (ECB).

The views expressed are those of the authors and do not necessarily reflect those of the $E C B$.

This paper can be downloaded without charge from http://www.ecb.europa.eu or from the Social Science Research Network electronic library at http://ssrn.com/abstract_id $=1559888$.

I The views expressed in this paper do not necessarily reflect those of the Bank of Finland. 2 Primary contact: Lally School of Management and Technology of Rensselaer Polytechnic Institute, 110 8th Street - Pittsburgh Building, Troy, NY, U.S.A., 12180, telephone: (5/8) 2762525 , e-mail: hasan@rpi.edu

3 European Central Bank - Payments and Market Infrastructure, Kaiserstrasse 29, 603II Frankfurt am Main, Germany.

4 Lally School of Management and Technology of Rensselaer Polytechnic Institute 110 8th Street, Pittsburgh Building, 
CC European Central Bank, 2010

\section{Address}

Kaiserstrasse 29

60311 Frankfurt am Main, Germany

Postal address

Postfach 160319

60066 Frankfurt am Main, Germany

Telephone

+496913440

Internet

http://www.ecb.europa.eu

Fax

+496913446000

All rights reserved.

Any reproduction, publication and reprint in the form of a different publication, whether printed or produced electronically, in whole or in part, is permitted only with the explicit written authorisation of the ECB or the authors.

Information on all of the papers published in the ECB Working Paper Series can be found on the ECB's website, http://www. ecb.europa.eu/pub/scientific/wps/date/ html/index.en.html

ISSN 1725-2806 (online) 


\section{CONTENTS}

Abstract

Non-technical summary

1 Introduction

2 Related literature and hypothesis development

2.1 Wealth effect of stock exchange M\&As and alliances

2.2 Horizontal and vertical activities

2.3 Domestic and international cooperative activities

2.4 Learning-by-doing effects

2.5 Difference in market development and governance

3 Data

3.1 Sample description

3.2 Variable definition and summary statistics

4 Tests and results

4.1 Short-run stock abnormal return and the integration activities

4.2 Long-run abnormal return and the integration activities

4.3 Accounting performance, liquidity, IPO and the integration activities

4.4 Robustness tests

5 Summary and conclusions

References

Tables and figures

Appendices 


\begin{abstract}
In recent years, demutualized stock exchanges have been increasingly engaging in M\&A and alliance activities. To examine the effect of these growth strategies on exchange shareholders' value creation, we focus on 14 public stock exchanges and investigate their short-run share price responses to the formation of $110 \mathrm{M} \& \mathrm{As}$ and alliances all over the world spanning the period 2000-2008. Our findings show that the average stock price responses for M\&As and alliances are positive. M\&As create more value than alliances. For alliances, joint ventures generate more value than non-equity alliances. More value accrues when the integration is horizontal (cross-border) than when it is vertical (domestic). Additionally, there is evidence of learning-by-doing effects in stock exchange integration activities. Finally, we find that the better the shareholder protection, accounting standards and capital market development in the partner exchange's country, the higher the merger and alliance premium for our sample exchange. These patterns are consistent when we examine the exchanges' long-run performance.
\end{abstract}

Keywords: exchanges; mergers and acquisitions; strategic alliances; joint ventures; network organization

JEL classification: L22; G32; D23 


\section{Non-technical summary}

Stock exchanges are fundamental components of modern and efficient financial markets. In recent years, stock exchanges have been increasingly engaging in M\&A and alliance activities. This trend can be attributed to the continuing globalization of capital markets, the increased demand for a larger exchange from institutional investors, innovations in technology removing many physical barriers to market access.

A key issue that has emerged is whether certain global integration activities create additional benefits and value for the shareholders of the partnering stock exchanges. Integration initiatives involving large, publicly traded stock exchanges were a relatively new phenomenon. Thus, there is little reliable information available to the market, or even to the involved exchanges themselves, about the best way of integration initiatives. It is also not clear which exchanges would be good at planning and executing mergers and alliances. The growing number of demutualized stock exchanges has also made this question more important and interesting as shareholders of these stock exchanges request management to maximize their share value.

This paper attempts to empirically examines whether and to what extent M\&As and alliances create value for the shareholders of the partnering stock exchanges. In addition, this study investigates the importance of differences in the characteristics of stock exchanges and integration activities in determining the valuation consequences across stock exchanges.

Our results show that on average the effects for M\&As and alliances are positive. M\&As create more value than alliances. For alliances, joint ventures generate more value 
than non-equity alliances. More value accrues when the integration is horizontal (crossborder) than when it is vertical (domestic). Additionally, there is evidence of learning-bydoing effects in stock exchange integration activities. Finally, we find that the better the shareholder protection, accounting standards and capital market development in the partner exchange's country, the higher the merger and alliance premium for our sample exchange. These patterns are consistent when we examine the exchanges' long-run performance.

This paper might turn out to be instructive to managers of stock exchanges about potential growth strategies. It might also guide investors when evaluating stock exchange shares. Given the importance of the stock exchange industry as a key component of financial markets, our study provides a better understanding on wealth effects of integration activities in this financial market infrastructure industry. 


\section{Introduction}

Stock exchanges are fundamental components of the financial market by providing an efficient trading place for all investors and a necessary governance mechanism for all listed firms. ${ }^{3}$ Recently, stock exchange mergers and acquisitions (M\&As) and alliances to expand the exchanges' businesses globally have been a trend all over the world since the $1990 \mathrm{~s}^{4}$ This trend can be attributed to the continuing globalization of capital markets, an increased demand for a larger exchange from institutional investors, innovations in technology removing many physical barriers to market access and demutualization of exchanges to gain access to new sources of capital (Knowledge@Wharton, 2006). ${ }^{5,6}$ These global consolidation initiatives among stock exchanges may well promote competition, improve governance mechanisms, enhance the effectiveness of cross-border capital flows, and lower the cost of equity financing for listed firms and thus have the potential to benefit the markets and investors all over the world (U.S. Securities and Exchange Commission, 2007). ${ }^{7}$

\footnotetext{
${ }^{3}$ Stock exchange disclosure (rules, monitoring, and enforcement) is an important element of investor protection and is positively associated with financial market development (Frost et al., 2006). Moreover, stock exchanges often dictate corporate governance standards for listed companies (Mendiola and O'Hara, 2003).

${ }^{4}$ For example, the NYSE Group and Euronext merged their businesses under a U.S. holding company, NYSE Euronext, to create the first trans-Atlantic equities market. In addition, Nasdaq recently announced an agreement to buy the Nordic stock-exchange operator, OMX.

${ }^{5}$ Starting in the early 1990 s, stock exchanges around the world have been undergoing major organizational and operational changes by converting from mutual, not-for-profit organizations to publicly-traded, forprofit firms. Following the example of the Stockholm Stock Exchange, institutions such as the Deutsche Börse, the London, Tokyo, Hong Kong and Toronto Stock Exchanges, and the Sydney Futures Exchange have demutualized. In the United States, the two largest stock markets (the New York Stock Exchange and NASDAQ) and the three main futures exchanges - the Chicago Mercantile Exchange, the Chicago Board of Trade, and the New York Mercantile Exchange - have all adopted the for-profit form.

${ }^{6}$ The advent of advanced computers and other forms of communication has allowed markets to operate worldwide, even as the marketplace itself has changed. Compared with the traditional floor trading activity, remote membership, electronic order book trading, alternative trading systems, and the internalization of order flow by financial intermediaries all emerge in recent years.

${ }^{7}$ Amihud and Mendelson (1986), Brennan and Subrahmanyam (1996) and Datar et al. (1998) find that liquid stocks gain more in value than illiquid stocks.
} 
A key issue that has emerged is whether certain global integration activities create value for the shareholders of the partnering stock exchanges. Because integration initiatives involving large, publicly traded stock exchanges were a relatively new phenomenon, there is little reliable information available to the market, or even to the involved exchanges themselves, regarding which types of mergers and alliances would create the most value or which exchanges would be good at planning and executing mergers and alliances. The growing number of demutualized stock exchanges has also made this question more important and interesting as shareholders of these stock exchanges request management to maximize their share value. ${ }^{8}$

Theoretically, it is still an open question whether stock exchange integration and co-operation create value for the stock exchange shareholders. On the one hand, consolidation efforts of stock exchanges can create new economies of scale to reduce trading costs (Arnold et al., 1999; Hasan and Malkamäki, 2001). Moreover, M\&As and alliances between two exchanges allow for better knowledge, skills and governance mechanisms transfer between partner exchanges (Tasi, 2001; Anand and Khanna, 2000; Dessein, 2005; Gomes-Casseres et al., 2006). Thus, shareholders can benefit from increased exchange revenue by attracting more investors and listing companies to increase trading volume and IPOs (Pagano et al., 2001; 2002).

On the other hand, difficult global regulatory issues that emerge in such global integration activities may offset the above mentioned beneficial gains for shareholders. In particular, any integration by stock exchanges needs to overcome the barriers to capital flows such as market frictions and differences in the price of risk across markets $\left(\mathrm{O}^{\prime}\right.$ Brien,

\footnotetext{
${ }^{8}$ In 1998 , only $38 \%$ of exchanges were for profit. In 2006, the number had increased to $75 \%$ (World Federation of Exchanges, 2007)
} 
1992; Korajczyk, 1997). The consolidation of exchanges would also reduce competition and opportunities for cross-listings (Scheinkman, 2001), which would decrease the efficiency and the future revenue for the partnering exchanges.

In this paper, we try to empirically answer this question by examining whether and to what extent M\&As and alliances create value for the shareholders of the partnering stock exchanges. In addition, we investigate the importance of differences in the characteristics of stock exchanges and integration activities in determining the valuation consequences across stock exchanges. Specifically, this paper focuses on 14 public stock exchanges and evaluates their short-run share price responses to the formation of 110 M\&As and strategic alliances all over the world during the 2000-2008 period. In our sample, we consider all major stock exchanges covering 95 percent in terms of world's total market capitalization. We employ a standard event study methodology using a market model and extend it by adding another US market return term to adapt to our multi-country event testing environment.

The overall results of this study reveal that the average stock price responses for stock exchange M\&As and alliances are positive. Stock exchange M\&As create more value than alliances. For alliances, joint ventures generate more value than non-equity alliances. More value accrues when the integration is horizontal (cross-border) than when it is vertical (domestic). ${ }^{9}$

In the cross-sectional analysis, we use the three-day cumulative abnormal return as the dependent variable and control for deal characteristics, learning-by-doing variables, exchange characteristics, macroeconomic variables, technological integration levels,

\footnotetext{
${ }^{9}$ We define a deal as a horizontal integration if the stock exchange integrates with another exchange with the similar business model.
} 
difference in legal system and language as well as country and year fixed effects. We obtain similar results to those shown in the event study. Additionally, there is evidence of learning-by-doing in stock exchange integration activities. Finally, we find that the better the shareholder protection, accounting standards, and capital market development in the partner exchange's country, the higher the merger and alliance premium for our sample stock exchange. These patterns are consistent when we examine the long-run performance measures such as the three-year buy-and-hold abnormal return, the change in ROA (ROE), the change in liquidity and the change in market capitalization of IPO between the year +2 and the year -2 .

This research contributes to the literature in several important ways. First, the research in the stock exchange industry focuses on theoretical analyses, liquidity measures and cost structures of financial exchanges. ${ }^{10}$ This paper complements the existing literature by examining the value creation for the shareholders of partnering stock exchanges. Second, to date, there is no empirical evidence regarding which types of integrations would create the most value in the stock exchange industry or which exchanges would be good at planning and executing integrations. This paper might turn out to be instructive to managers of stock exchanges about potential growth strategies. This paper might also guide investors when evaluating stock exchange shares. Third, given the importance of the stock exchange industry as a key component of the financial market, our study provides a better understanding on wealth effect of integration

\footnotetext{
${ }^{10}$ Pirrong (1999) presents theory and evidence regarding the economics of exchanges themselves. Santos and Scheinkman (2001) construct a theoretical model and show that competition among exchanges leads to an efficient, but constrained outcome. Nielsson (2008) shows that Euronext stock exchange mergers have increased liquidity of the firms listed on them. Hasan and Malkamäki (2001) confirm the existence of economies of scale and scope among the stock exchanges. Serifsoy (2007) reveals that diversified stock exchanges are mostly less efficient than exchanges that remain focused on the cash market.
} 
activities this financial market infrastructure industry. Thus, this study complements the existing M\&A and alliance research in other industries such as banking industry (DeLong, 2001). Finally, DeLong and Deyound (2007) find that banks and investors learn by observing the previous bank mergers to apply that knowledge to execute and evaluate the subsequent mergers. Our paper complements this strand of literature by showing the existence of the experience effects in the integration activities of the stock exchange industry.

The paper is organized as follows: Section 2 describes the related literature and develops a set of hypotheses. Section 3 describes the data collection procedures and the resulting sample. Empirical results are presented in Section 4. The final section presents our conclusions.

\section{Related literature and hypothesis development}

\subsection{Wealth effect of stock exchange $M \& A s$ and alliances}

The existing literature has confirmed the existence of economies of scale and scope among the stock exchanges (Hasan and Malkamäki, 2001). Nielsson (2008) shows that Euronext stock exchange mergers have increased liquidity of the firms listed on them. Arnold et al. (1999) show that the mergers of US regional stock exchanges attracted market share and resulted in narrower bid-ask spreads. Further, Krishnamurti et al. (2003) argue that small and medium sized investors would be attracted to the exchange scoring higher on these variables: use of technology, internal control systems, transparency and investor protection. Thus, shareholders of stock exchanges would benefit from increased revenue by increased trading volume and IPOs. Additionally, M\&As and alliances 
between two exchanges enable them to acquire knowledge, skills and governance mechanisms from partner exchanges (Tasi, 2001; Anand and Khanna, 2000; Dessein, 2005; Gomes-Casseres et al., 2006). Thus, shareholders of stock exchanges would also benefit from the synergy gains from improved knowledge, skills and governance mechanisms.

Despite the several reasons for M\&As and alliances between exchanges, stock exchanges cannot compete as ordinary business enterprises because of the manner in which they are regulated and because they function as self-regulatory organizations (U.S. Securities and Exchange Commission, 2007). Thus, such deals have to incur some costs to overcome legal barriers to benefit from synergy gains. Such integrations also need to overcome the other barriers to capital flows, such as market frictions and differences of price of risk across markets (O’Brien, 1992; Korajczyk, 1997). The integration activities of exchanges would also reduce competition and opportunities for cross-listings (Scheinkman, 2001). This would decrease the efficiency and the future revenue for the partnering exchanges. In summary, it is still an empirical question whether the integration activity of stock exchanges will create value for their shareholders. We summarize the related hypotheses as follows:

Hypothesis 1: The average stock price response to the announcement of a stock exchange integration activity (M\&A, joint venture, or non-equity alliance) is positive.

Another important question for shareholders of stock exchanges is that which growth strategy is relatively better. The available growth strategy can range from a simple contract (herein defined as non-equity alliance) to an M\&A; joint ventures occupy an intermediate point. Drafting, organization and coordination costs increase as one becomes engaged from a non-equity alliance to an M\&A. Economic efficiency implies 
that firms prefer a non-equity alliance over an intermediate status or an M\&A (Williamson, 1979). Agency theory makes the same prediction since non-equity alliances avoid the agency costs associated with management's empire-building behavior by an M\&A (Jensen, 1986a, b).

On the other hand, M\&As might be preferred compared to joint ventures or alliances in the stock exchange industry. The reason is that new companies' listing and transaction fees are the most important revenue source of stock exchanges (Aggarwal, 2002). Equity-involved integrations can allow stock exchange to get materially involved with the new business (Arnold et al., 1999). Based on these arguments, we investigate the following two hypotheses.

Hypothesis 2a: More value accrues when the stock exchanges choose M\&As over joint ventures.

Hypothesis 2b: More value accrues when the stock exchanges choose joint ventures over non-equity alliances.

\subsection{Horizontal and vertical activities}

In recent years stock exchanges have been increasingly diversifying their operations into related business areas such as derivatives trading, post-trading services and software sales. We define a deal as a horizontal integration if the stock exchange integrates with another exchange with the similar business model. We define a deal as a vertical integration if the stock exchange integrates with another exchange with the different business focus. M\&As and alliances between two partners with the same business lines enable stock exchanges to better acquire knowledge, skills and governance mechanisms from partner exchanges than vertical deals (Tasi, 2001; Anand and Khanna, 2000; Dessein, 2005; Gomes-Casseres et al., 2006). Moreover, they enhance the stock 
exchange's market power in its own country or other countries. The existing literature (Serifsoy, 2007) has shown that exchanges that diversify into related activities are mostly less efficient than exchanges that remain focused on the cash market. In our paper, we hypothesize that:

Hypothesis 3: More value accrues when the stock exchanges' integration activities are horizontal.

\subsection{Domestic and international cooperative activities}

The demand for global exchanges has grown as more and more investors, both large and small, have begun to look beyond their own countries' borders for investment opportunities (U.S. Securities and Exchange Commission, 2007). Cross-border business opportunities are an important driver of stock exchange consolidation activities (Nielsson, 2008). Thus, we expect that cross-border integration activities can create more value as a result of increased overseas business opportunities than domestic deals. Additionally, there is a bigger difference in use of technology, internal control systems, transparency, and investor protection between the two exchanges located in different countries than those in the same country. Thus, the synergy gain in cross-border deals should be much larger than that obtained in domestic integration activities. Our hypothesis can be formalized as follows:

Hypothesis 4: More value accrues when the stock exchange's integration activities are cross-border.

\subsection{Learning-by-doing effects}

The existing literature confirms that the experience matters in corporate decision making process. For example, Arrow (1962) and Hartley and Corcoran (1978) find that 
the differences of efficiency between British and U.S. airframe manufacturers after World War II are caused by the difference in their experience. Ghemawat (1985) find that the experience effects also exist in other industries. The stock exchange industry is a highly regulated industry and strict regulation had prevented exchanges from operating across country borders (U.S. Securities and Exchange Commission, 2007). Consolidations involving large, publicly traded exchanges were a relatively new phenomenon in the 2000s (Nielsson, 2008). There is little reliable information available to the market, or even to the exchanges themselves, about best practices for exchange growth strategies. As more exchange consolidations occur over time, however, it is reasonable to expect that exchanges learn to better plan and execute integration activities from their previous experience. Similarly, it is reasonable to expect that investors learn to better value exchange consolidation activities as they increasingly observe and evaluate these initiatives. Based on these arguments, we hypothesize that:

Hypothesis 5: More value accrues when the stock exchanges have undertaken more previous integration activities.

\subsection{Difference in market development and governance}

In cross-border deals, the difference in stock market development and investor protection between the partner' country and the sample exchange' country might also influence shareholder value creation. The more developed a stock market is, the more liquidity it can provide. Thus, when the partnering stock exchange locates in the country with a more developed stock market, there should be more synergy gain for the sample stock exchange from increased liquidity. Similarly, the stock exchange with relatively low governance standards may benefit from the governance transfer effect in the process 
of the consolidation. Specifically, stock exchanges learn to govern the firms more effectively from partner exchanges. ${ }^{11}$ Frost et al. (2006) argue that stock exchange governance mechanism is a concrete manifestation of country-level investor protection in the securities markets. Thus, when the partnering stock exchange locates in the country with higher investor protection, there should be more synergy gain for the sample stock exchange from increased governance effects. In our paper, we hypothesize that:

Hypothesis 6a: The better market development in the partner exchange's country, the higher the merger and alliance premium for the sample stock exchange.

Hypothesis 6b: The better country-level governance in the partner exchange's country, the higher the merger and alliance premium for the sample stock exchange.

\section{Data}

\subsection{Sample description}

Our sample includes 14 public stock exchanges, which have stock price data available in Datastream. Table 1 presents the distribution of these public stock exchange companies across countries. As shown in Table 1, most of the public stock exchanges are located in the developed countries such as the United States and the United Kingdom. Then, we collected M\&A and alliance announcement data on these stock exchanges during the period from January 2000 to August 2008 from a number of sources such as the newsletters and press releases from the World Federation of Exchanges (WFE, 20002008) and the European Federation of Securities Exchanges (FESE, 2000-2008). Another important data source is the internet, press archives and ad hoc announcements of the individual stock exchanges involved in the integration deals. For an event to be included

\footnotetext{
${ }^{11}$ In the announcement of the alliance between New York Stock and Tokyo Stock Exchange, one potential collaboration area is regulation and governance. More details can be seen in Appendix A.
} 
in the analysis, the stock price data around the event for the involved public stock exchange must be available in the DataStream database. If one stock exchange in the sample announces the purchase or an alliance with another stock exchange within six months of the previous announcement, we drop the subsequent one from the sample. We also drop 7 uncompleted M\&A deals (6 acquirers are publicly traded exchanges).

Our analysis identified 110 announcements of M\&As and alliances by these 14 public stock exchanges. ${ }^{12}$ In our sample, there are $30 \mathrm{M} \& \mathrm{~A}$ events. They are all at least partially stock-financed and there are no hostile deals. Although we only focus on acquirers' stock response and exclude the targets from our sample, we investigate the ownership structure of target exchanges. We find that only 3 target stock exchanges are publicly traded companies. This result suggests that only a small percentage of exchange M\&As combined two publicly traded exchanges. Additionally, there are 16 stock exchange joint ventures and 64 non-equity alliances in our sample. Two partners are both public stock exchanges in 4 joint ventures and 7 non-equity alliances. We include each partner's announcement as one observation in our sample. Thus, in total, we have 20 observations for joint ventures ( 8 observations from 4 joint ventures for which two partners are both public stock exchanges and 12 observations from 12 joint ventures for which one partner is a public stock exchange and the other one is nonpublic stock exchange) and 71 event observations for non-equity alliances (14 observations from 7 non-equity alliances for which two partners are both public stock exchanges and 57 observations from 57 non-equity alliances for which one partner is a public stock exchange and the other one is nonpublic stock exchange). Adding 30 observations for

\footnotetext{
${ }^{12}$ In total, 102 stock exchanges are involved in these deals. These account from roughly $72 \%$ of the total number of exchanges in the world. In terms of market capitalization, however, the stock exchanges in the sample represent over $95 \%$ of the universe.
} 
M\&As together, we have 121 observations in our sample. Each observation represents an integration event (M\&A, joint venture, or non-equity alliance) by a single publicly traded exchange.

Panel A of Table 2 presents the sample events by year of announcement. Inspection of Table 2 shows that the number of exchange integrations is not evenly distributed over the 2000-2008 sample period. The largest number of announcements of M\&A and strategic alliances in one year is 28 in 2007, followed by 20 in 2006. Panel B classifies the M\&A and alliances. About $85 \%$ of total stock exchange integration events are horizontal and 90\% are cross-border. These results suggest that stock exchanges prefer horizontal and cross-border consolidations. Panel C presents the sample events by the type of technological integration. The results imply that one type of technological integration does not dominate our sample. In addition, we provide a brief description of each of the types of consolidation agreements in the Appendix A.

We also check whether alliances represent experimental organizational forms and would eventually evolve into joint ventures or mergers as proposed by Mody (1993). Our result does not support this assertion. Within four years following the formation of an alliance, only four of our sample alliances evolved into a more permanent form of relationship (Joint Ventures or M\&As). This result is consistent with the findings in the sample of US business firms by Chan et al. (1997). ${ }^{13}$

\footnotetext{
${ }^{13}$ They find that within four years of the formation of an alliance, only five of their sample alliances evolved into a more permanent form of relationship (joint ventures or M\&As).
} 


\subsection{Variable definition and summary statistics}

In this subsection, we discuss the measurement of four categories of variables: exchange performance measures, deal-specific characteristics, exchange characteristics as well as country-level variables that controlling for macroeconomic conditions, the difference in legal system and language and the difference in governance and financial market development. A detailed description of the variable definitions can also be found in Appendix B.

\subsubsection{Exchange performance measures}

Shareholder value creation, the outcome variable of interest, can be measured in various ways, which are presented in the following. The objective of this study is to answer whether the consolidation of stock exchanges create value for exchange shareholders. For this purpose, we use the variable $C A R[-1,1]$ to represent the three-day announcement abnormal return calculated based on the extended market model. The extended market model parameters are estimated over the period $(-150,-31) .{ }^{14}$ Examining short-run stock price response instead of the long-run performance measures, enables us to keep more observations in our sample.

Nonetheless, to append to the overall shareholder value creation discussion, the three-year buy-and-hold abnormal return $\left(B H A R_{1,36}\right)$ is introduced in Section 5.2, which captures the long-term dimension of shareholder value creation. In Section 5.3, we also introduce the variable, the difference in industry-adjusted ROE (ROA) between the year +2 and the year -2 to measure the change of exchange accounting performance. In Section 5.4, we introduce the variable, the difference in industry-adjusted value of share

\footnotetext{
${ }^{14}$ A more detailed description of this measure can be found in section 5.1.1.
} 
trading scaled by market capitalization of listed firms between the year +2 and the year -2 to measure the change of exchange liquidity. To measure the change of IPO volume, we introduce the variable, the difference in industry-adjusted market capitalization of IPO scaled by market capitalization of listed firms between the year +2 and the year -2 .

\subsubsection{Deal characteristics}

In our estimation, we control for several deal characteristics as follows. InterType is equal to 0 when the deal is an M\&A, 1 when the deal is a joint venture, and 2 when the deal is a non-equity alliance. CrossBorder is a dummy variable, which is equal to 1 when the deal is a cross-border transaction, and is otherwise 0. Horizontal is a dummy variable, which equals 1 when the deal is a horizontal transaction, and is otherwise 0 . Public is a dummy variable, which equals 1 when the partner is a publicly traded exchange, and is otherwise 0 . TechnologicalIntegration is a series of dummy variables to indicate the type of technological integration, i.e. outsourcing, common access, common systems, common operations, complete system integration, and other type of integration. ${ }^{15}$

\subsubsection{Learning-by-doing variables}

Stock exchanges might engage in several integration activities during our sample period. By this, exchanges can learn lessons and build up institutional experience from these activities. We construct and include the variables, which measure the number of stock exchange own integration activities during the previous period to control for the potential effects of active, internal learning by doing. Specifically, NoPreMA is the

\footnotetext{
${ }^{15}$ Hasan et al. (2003) report increased cost and revenue efficiency of exchanges associated with investment in technology-related developments.
} 
number of previous M\&A events experienced by a given exchange, NoPreJV is the number of previous joint venture events experienced by a given exchange, and NoPreAL is the number of previous non-equity alliance events experienced by a given exchange.

\subsubsection{Exchange characteristics}

We also control for stock exchange specific characteristics including firm size, Tobin's q, leverage, and cash flow. All these variables are measured at the fiscal year-end prior to the integration announcement. The source for these variables is the Worldscope database. Specifically, exchange size is defined as the log transformation of total assets (Log (TotalAssets)). Tobin's q is the ratio of market value of assets over book value of assets $(Q)$. Leverage refers to the total liabilities divided by total assets (Leverage) Cash flow is equal to operating income before depreciation minus interest expenses, income taxes and capital expenditures, scaled by total assets (CashFlow).

\subsubsection{Country-level variables}

We use the logarithm of GDP per capita and the logarithm of GDP growth to control for the countries' macroeconomic conditions, which come from World Development Indicator. If two partnering stock exchanges located in different countries, the difference in legal system and language might create an integration barrier and reduce potential synergy gain. To control for these effects, we construct two dummy variables: SameLanguage, which equals one when two partnering stock exchanges' countries share the same language reported in atlas and zero otherwise and SameLegalSystem, which 
equals one when two partnering stock exchanges' countries share the same legal origin reported in La Porta et al. (1998) and zero otherwise.

To measure the difference in stock market development between the partner stock exchange' country and the sample stock exchange's country, we construct the difference of three variables that are from World Development Indicator: market capitalization of listed stock scaled by GDP, stock traded turnover ratio, and total value of stock traded scaled by GDP (DifMarketToGDP, DifTurnover and DifStockTradeToGDP). We took the country-level indices on shareholder rights and accounting standards, and the efficiency of the legal system, from La Porta et al. (1998) to measure the potential governance transfer effect because stock exchange governance mechanism can be regarded as a concrete manifestation of country-level investor protection in the securities markets (Frost et al., 2006). Then we use the product of the shareholder rights index and the efficiency of the legal system to construct the index of shareholder protection. The difference of the corresponding indices (shareholder protection index and accounting standards) between the partner stock exchange' country and the sample stock exchange's country (DifShareholderProtection and DifAccountingStandards) provides an indication of the difference in investor protection between the partnering stock exchanges' countries.

\subsubsection{Summary statistics}

Table 3 presents the summary statistics of our variables used in the empirical test. Exchange performance measures and exchange characteristics are winsorized at the $1^{\text {st }}$ and $99^{\text {th }}$ percentiles to eliminate the effect of outliers. The summary statistics of these variables are consistent with the findings reported in the existing literature. In Panel C, 
we observe that some exchanges experience several M\&A and alliance events in our sample period. For example, the maximum value of the previous M\&A (NoPreMA), joint venture (NoPreJV) and alliances (NoPreAL) events are respectively 6, 3 and 11 . As shown in Panels $G$ and $H$, the mean values of the difference in capital market development and legal environment are all positive. These results suggest that most of the public stock exchanges are located in the countries with relatively more developed capital markets and legal systems.

\section{Tests and results}

\subsection{Short-run stock abnormal return and the integration activities}

\subsubsection{Event study findings}

We conduct an event study to measure the stock price response associated with the announcement of stock exchange M\&As and alliances. Because of the multi-country nature of our event study and most of the capital markets around the world are influenced by the US market, we extend the market model by adding a US market return term to calculate abnormal return. The linear equation is specified as:

$r_{i t}=\alpha_{i}+\beta_{1, i} r_{m, j t}+\beta_{2, i}\left[r_{U S, t}+e_{j t}\right]+\varepsilon_{i t}$

Where $i$ is the exchange index, $j$ is the country market index, $t$ represents a one-day period time index and $r_{i, t}$ represents the daily rates of return. These variables are calculated for all stocks in our sample using DataStream's total return index (RI), which includes dividends as well as price changes. $r_{m, j t}$ is a domestic market return, and $r_{U S, t}$ is the U.S market return. ${ }^{16,17}$ The rate of change in the exchange rate per US dollar is $e_{j t}$.

\footnotetext{
${ }^{16}$ Local market index data is the exchange stock associated market index reported in DataStream.
} 
When we calculate Equation (1) using US data, we set $\beta_{2, i}$ to zero. The announcement day is day zero, the estimation period for the market model estimate begins on day -150 and ends on day -31 . We have set the cut-off at 30 days before the announcement date because one of the weakest points of event studies is information leakage, i.e., some inside information is known before the actual event announcement. However, this might not fully solve the problem if the mergers and acquisitions and strategic alliances had been in the making for a long time. Nonetheless, based on Figure 1, the cut-off at 30 days before the announcement date reasonably avoids the information leakage problem. The graphs also show that establishing strategic relationships is good news and creates significant value for the shareholders of the partnering stock exchanges.

Significance tests in our event study are based on a standardized parametric test statistic constructed to determine whether the mean abnormal return is significantly different than zero (see Mackinlay, 1997, for a detailed description of the test statistics and their calculation). Campbell et al. (2007) find that a non-parametric test does a better job than a parametric test in a multi-country event study. Thus, we also report the results of Wilcoxon signed-rank tests.

Panel A of Table 4 shows that the three-day cumulative abnormal return is a statistically significant $1.4 \%(Z$-statistic $=2.24)$ for stock exchange M\&As, $1.1 \%(Z$ statistic $=2.51)$ for stock exchange joint ventures and $0.95 \%(Z$-statistic $=2.85)$ for stock exchange non-equity alliances. This evidence suggests that establishing strategic relationships creates significant value for the shareholders of the partnering stock exchanges. The non-parametric tests confirm these findings.

\footnotetext{
${ }^{17}$ We use the S\&P 500 index to calculate US market return. When we use the Dow Jones Index to calculate US market return, we obtain similar results.
} 
Our finding that average stock price responses around the announcement of stock exchange M\&A and alliances are all significantly positive is consistent with the existing literature. Chang (1998) finds that in M\&A involving a private target firm and stock payment, bidders experience a positive abnormal return. For the joint ventures, McConnell and Nantell (1985) find significant wealth gains from joint ventures. For the non-equity alliance, Chan et al. (1997) reveal that the average stock price response to the formation of a non-equity alliance is positive.

Panel B of Table 4 compares cumulative abnormal return $[-1,1]$ among two of the three groups of events: stock exchange M\&As, joint ventures and non-equity alliances. The mean value of cumulative abnormal return $[-1,1]$ of stock exchange M\&As is significantly higher than that of joint ventures $(\mathrm{T}$-statistic $=4.42) .{ }^{18}$ Similarly, the mean value of the cumulative abnormal return $[-1,1]$ of stock exchange joint ventures is significantly higher than that of non-equity alliances $(\mathrm{T}$-statistic $=4.28)$.

We further classify our sample into different groups to examine the patterns in subsamples. As shown in Panel A of Table 5, the three-day cumulative abnormal return is statistically significant $2 \%(Z$-statistic $=3.05)$ for cross-border stock exchange M\&As, $1.13 \%(Z$-statistic $=2.62)$ for cross-border stock exchange joint ventures and $1.3 \%(Z$ statistic $=3.92)$ for cross-border stock exchange alliances. The three-day cumulative abnormal returns for cross-border integration events are higher and more pronounced than for other integration events. In contrast, the three-day cumulative abnormal return is not statistically significant and has a lower mean value for domestic integration events.

\footnotetext{
${ }^{18}$ We acknowledge that sample acquisitions all appear to be partially stock financed. This should place some negative downward pressure on bidder returns because of the usual method-of-payment effect arising from negative information revelation when stock is issued. This will impart a negative bias on the estimates of the value creation accruing to bidding shareholders from the consummation of a deal.
} 
This evidence suggests that more value accrues for the shareholders of the partnering stock exchanges where cross-border strategic relationships are established. The nonparametric tests (sign tests) confirm these findings. Panel B of Table 5 shows similar results, suggesting that more value accrues for the shareholders of the partnering stock exchanges where horizontal strategic relationships are established.

Six acquirers are publicly traded exchanges in seven uncompleted M\&A deals. We examine the stock price response for ther acquirer stock exchange when the deal failed. The results are shown in Panel $\mathrm{C}$ of Table 5. We observe that the three-day cumulative abnormal return is a statistically significant $-2.76 \%(Z$-statistic $=-3.78)$ for acquirer stock exchanges, insignificant $0.14 \%($ Z-statistic $=0.03)$ for target stock exchanges in failed M\&As. These results suggest that failed M\&As reduce shareholder value of acquirer exchanges.

As indicated earlier, in our sample there are three M\&As, four joint ventures and seven non-equity-alliances for which price data are available for two partners. In this subsample, we examine whether there are wealth transfers between the larger and smaller partners in the alliance. We use the market value of each firm's common stock 31 trading days before the announcement of the integration to measure the relative size. Panel D of Table 5 compares the average cumulative abnormal return $[-1,1]$, the average market value on event day -31 , and the change in wealth in the time interval $[-1,1]$ around the announcement day (market value on event day -31 multiplied by the average abnormal return $[-1,1])$ for the sub-groups defined by the relative sizes of the alliance partner exchanges). 
In three M\&As deals, The average market value of the acquirers is $\$ 4,022.33$ million, which is on average more than three times that of the targets $(\$ 1,065.45$ million). Both acquirer and target exchanges experience a significant three-day cumulative abnormal return. These results also suggest that the target exchanges in the M\&As receive a larger abnormal return than the acquirer exchanges. However, the wealth gains are almost equal.

In four joint ventures and seven non-equity alliances, the average market value of the larger partner is on average more than ten times that of the smaller ones. The smaller exchanges experience a significant three-day cumulative abnormal return. The larger exchanges experience an insignificant cumulative abnormal. These results suggest that smaller exchanges in the alliance receive a larger abnormal return than the larger exchange. However, the wealth gains are almost equal. We also test the potential wealth transfer between the larger and smaller exchange. The evidence shows that the correlation between the wealth increases experienced by the paired larger and smaller exchange is not significant. These results imply that the wealth is created by the formation of exchange joint venture and non-equity alliances and there is no evidence of wealth transfer between the partners.

\subsubsection{Cross-sectional analysis}

In this section, we analyze the cross-sectional differences in the short-run abnormal returns for the M\&A and alliance announcements using regression analysis. The model specification is as follows: 
$C A R[-1,1]=\alpha_{i}+\beta_{1}$ DealCharacteristics $+\beta_{2}$ LearningByDoing $+\beta_{3}$ ExchangeCharactistics $+\beta_{4}$

MacroDevelopment $+\beta_{5}$ TechnologicalIntegration $+\beta_{6}$ DifLegalandLanguage $+\varepsilon$

where the dependent variable $C A R[-1,1]$ is the three-day announcement abnormal return. The independent variable DealCharacteristics includes InterType (equal to 0 when the deal is an M\&A, 1 when the deal is a joint venture, and 2 when the deal is a non-equity alliance), Crossborder (equal to 1 when the deal is a cross-border transaction, otherwise 0), and Horizontal (equal to 1 when the deal is a horizontal transaction, otherwise 0 ). We use the number of previous integration activities (NoPreMA, NoPreJV and NoPreAL) to measure learning-by-doing effects (LearningByDoing). The variables to control for exchange characteristics (ExchangeCharactistics) include exchange size (Log(TotalAssets)), Tobin's q $(Q)$, leverage (Leverage), and cash flow (CashFlow). We use the logarithm of GDP per capita ( $\log ($ GDPPerCapital)) and the logarithm of GDP growth (Log(GDPGrowth) $)$ to control for the countries' macroeconomic developments (MacroDevelopment). We also control for the type of technological integration (TechnologicalIntegration) in the regression, whether it is mainly outsourcing, common access, common systems, common operations, complete system integration, or some other type of integration. We use the variable Samelanguage and SameLegalSystem to control for the difference in language and legal system (DifLegalandLanguage). Country and year fixed effects are also included in our estimation.

We argue that there are no potential endogeneity issues between exchange integration events and value creation although there are various motives for these activities. First, with regards to reverse causality, if stock return was already increasing it 
should not encourage an integration activity. In contrast, low initial stock return may cause the integration events to occur, but this does not result in any statistical problems. In addition, these particular exchanges may have decided to pursue and adopt a certain type of integration (M\&As, joint ventures or alliances) because of relatively low turnover. However, such a selection issue does not bias our statistical analysis. The regression coefficients still capture the effects of the integration activities on shareholder value creation. Second, in theory there may be a third factor causing both shareholder value creation and integration events to occur, leading to omitted variable problems. However, if the variables, which cause stock return to go up, were already improving before the events, there would be no reason to integrate in the first place. Thus, even though variation in a third factor may cause stock return to increase, it will not simultaneously be driving integrations events and thereby induce omitted variable problems.

The results are shown in Table 6. We uncover three important findings. First, more value accrues when the deal is a stock exchange M\&A compared with a joint venture or alliance. Second, horizontal stock exchange integration activities create more synergies than vertical ones. Finally, cross-border stock exchange integration activities create more synergies than vertical ones. These results are not only statistically significant, but also economically significant. On average, the three-day cumulative abnormal return of exchange M\&As (joint ventures) is on average $0.7 \%$ higher than that of exchange joint ventures (non-equity alliances). The three-day cumulative abnormal return of horizontal integrations is $2.8 \%$ higher than that of vertical integrations. Cross border consolidations generate abnormal returns $2.4 \%$ higher than domestic ones. 
In contrast to vertical initiatives, horizontal stock exchange integration activities create synergies. This finding is consistent with the results reported in the existing literature. Ravenscraft and Scherer (1987), Bhagat et al. (1990) and Kaplan and Weisbach (1992) show that only mergers between firms in related businesses are likely to generate operating synergies. Johnson and Houston (2000) reveal that only horizontal joint ventures create value for shareholders while vertical ones do not. Chan et al. (1997) find that when non-equity alliances involve a transfer or pooling of technology, the average stock price response is positive for horizontal alliances and there is no significant abnormal return for vertical ones.

It is worth emphasizing that the coefficients of the learning-by-doing variables (NoPreMA, NoPreJV and NoPreAL) are negative and statistically significant. If the exchange experienced one more M\&A (joint venture, non-equity alliance), the three-day cumulative abnormal return of the next integration activity will increase by $0.012 \%$ $(0.010 \%, 0.014 \%)$. Thus, we find evidence to suggest that exchanges engaging in integration activities tend to perform better after they have some experience from previous integration activities. This finding most likely reflects the fact that complicated and different regulations in various countries encountered by stock exchanges make previous experiences valuable. We also find that exchange size (Log (TotalAssets)) is inversely related to abnormal return. These results are consistent with the existing literature. The coefficients of SameLanguage and SameLegalSystem are both insignificantly positive. These results are not reported for the brevity. 


\subsubsection{The impact of the difference in market development}

In cross-border deals, the difference in stock market development between two partners' countries might also influence shareholder value creation. The more developed a stock market is, the more liquidity it can provide. Thus, when the partnering stock exchange locates in the country with a more developed stock market, there should be more synergy gain from increased liquidity. In this sub-section, we examine how the difference in capital market development between the countries of the partnering stock exchanges influences the abnormal return. The model specification is as follows:

CAR $[1,1]=\alpha+\beta_{1}$ DealCharacteristics $+\beta_{2}$ LearningByDoing $+\beta_{3}$ ExchangeCharactistics $+\beta_{4}$ MacroDevelopment $+\beta_{5}$ TechnologicalIntegration $+\beta_{6}$ DifLegalandLanguage $+\beta_{7}$ DifMarketDevelopment $+\varepsilon$

Compared with equation (2), we add another term (DifMarketToGDP, DifTurnover or DifStockTradeToGDP) to measure the difference in capital market development between the countries of the participating stock exchanges (DifMarketDevelopment). ${ }^{19}$ As shown in Table 7, our main results do not change. The coefficients of the variables DifMarketToGDP, DifTurnover and DifStockTradeToGDP are significantly negative. One percentage of difference in the capital market development between the partner stock exchange's country and the sample exchange's country (measured by market capitalization of listed stock scaled by GDP) will lead to a $0.169 \%$ increase of the threeday cumulative abnormal return. These results suggest that the better the capital market

\footnotetext{
${ }^{19}$ Because these three variables are correlated, we add one into the regression equation at a time.
} 
development in the partner's country, the higher the merger and alliance premium for our sample exchange.

\subsubsection{The impact of the difference in governance}

Similarly, the stock exchange with relatively low governance standards may benefit from the governance transfer effect in the process of the consolidation. Frost et al. (2006) argue that stock exchange governance mechanism is a concrete manifestation of country-level investor protection in the securities markets. Thus, when the partnering stock exchange locates in the country with higher investor protection, there should be more synergy gain for our sample exchange from increased governance effects. In this sub-section, we assemble country-level corporate governance indices and seek to examine how the difference in the legal environment of the countries of the stock exchanges influences the abnormal return. The model specification is as follows:

$C A R[1,1]=\alpha+\beta_{1}$ DealCharacteristics $+\beta_{2}$ LearningByDoing $+\beta_{3}$ ExchangeCharactistics $+\beta_{4}$ MacroDevelopment ${ }_{i}+\beta_{5}$ TechnologicalIntegration $+\beta_{6}$ DifLegalandLanguage $+\beta_{7}$ DifMarketDevelopment $+\beta_{8}$ DifGovernance $+\varepsilon$

Compared with equation (3), we add another term (DifShareholderProtection or DifAccountingStandards) to measure the difference in the legal environment between the countries of the stock exchanges (DifGovernance). ${ }^{20}$ As shown in Table 8, our main

\footnotetext{
${ }^{20}$ Because these three variables are correlated, we add one into the regression equation at a time.
} 
results still hold. ${ }^{21}$ The coefficients of the variables DifShareholderProtection and DifAccountingStandards are significantly positive. One percentage of difference in the legal environment between the partner exchange's country and the sample exchange's country (measured by the shareholder protection index) will increase the three-day cumulative abnormal return by $0.028 \%$. These results suggest that the better the legal system in the partner's country, the higher the merger and alliance premium.

\subsection{Long-run abnormal return and the integration activities}

From a stock exchange shareholder's viewpoint, the long-run stock return after the integrations might be more important and valuable than the short-run stock return. By looking at the long-term patterns in stock returns, we are able to test whether the positive reaction to the exchange integration is a sign of temporary optimism by investors who newly gain remote access in equity trading, or whether the price reaction is permanent implying an increase in the shareholders' wealth. To formally address this issue, first, we examine the three-year buy-and-hold abnormal return of the partnering exchange. The three-year period includes the following 36 months where months are defined as successive 21-trading-day periods relative to the announcement date. Thus, month 1 consists of event days 2-22; month 2 consists of event days 23-43, etc. The three-year buy-and-hold abnormal return $B H A R_{1,36}$ is calculated as below:

$$
B_{H A R_{1,36}}=\prod_{1}^{36}\left(1+R_{i, t}\right)-\prod_{1}^{36}\left(1+R_{m, t}\right)
$$

\footnotetext{
${ }^{21}$ In the reported results, we only control for DifTurnover. Our results do not change when we control for DifMarketToGDP or DifStockTradeToGDP.
} 
where $R_{i, t}$ is the monthly return and $R_{m, t}$ is the benchmark return, which is the valueweighted exchange industry return. ${ }^{22,23}$

The results show that the three-year abnormal return is significantly positive. The t-statistic is 3.34 in T-test; the z-statistic is 3.12 in Wilcoxon signed-rank test. ${ }^{24}$ These results suggest that partnering exchanges outperform the value-weighted exchange industry return over the three-year horizon.

In addition, we use the three-year buy-and-hold abnormal return $B H A R_{1,36}$ as the dependent variable and conduct a multivariate analysis. The model specification is as follows:

BHAR $_{1,36}=\alpha+\beta_{1}$ DealCharacteristics ${ }_{i}+\beta_{2}$ LearningByDoing $+\beta_{3}$ ExchangeCharactistics $+\beta_{4}$ MacroDevelopment $+\beta_{5}$ TechnologicalIntegration ${ }_{i}+\beta_{6}$ DifLegalandLanguage $+\beta_{7}$ DifMarketDevelopment $+\beta_{8}$ DifGovernance $+\varepsilon$

The results are reported in Table 9. The findings are consistent with the results of the short-run abnormal return analysis. First, there is more improvement in long-run abnormal return when the deal is an M\&A compared with a joint venture or an alliance. Second, horizontal (cross-border) stock exchange integration activities have higher longrun abnormal return for the stock exchange than vertical (domestic) ones. We also find that the learning-by-doing effect still holds in terms of the stock exchange's accounting

\footnotetext{
${ }^{22}$ Whether we use market index return or equal-weighted industry average return as the bench return, we draw the same conclusion. The results are not reported, but are available upon request.

${ }^{23}$ When we calculate the value-weighted industry return for a sample exchange, we do not include that sample exchange.

${ }^{24}$ See Barber and Lyon (1997) for more details about various measures and statistical tests used to detect long-run abnormal return.
} 
ratio performance. Finally, the better the shareholder protection, accounting standards, and capital market development in the partner's country, the higher long-run abnormal return for the stock exchange.

\subsection{Accounting performance, liquidity, IPO and the integration activities}

In this subsection, we use accounting ratios, i.e. ROA and ROE, to measure exchange performance. These accounting ratios capture actual financial performance over a period of time, while market returns are forward-looking measures of expected earnings. ${ }^{25}$ First, we calculate industry-adjusted accounting performance measures by subtracting asset-weighted industry performance from the levels of each of two performance metrics (ROA and ROE) in the years -2 and $+2 .{ }^{26,27}$ Using T-tests and Wilcoxon signed-rank tests, the evidence shows that industry-adjusted accounting performance measures are significantly positive in the years tested. The results suggest that exchanges entering into M\&A and alliances tend to display superior performance relative to their industry counterparts both prior to and after the announcement of integration activities. We also use T-tests and Wilcoxon rank-sum tests to determine whether the differences in industry-adjusted performance measures between the year -2 and the year +2 are statistically significant. We find evidence that performance improves significantly from the year -2 to the year $+2 .{ }^{28}$ Second, we conduct a multivariate analysis

\footnotetext{
${ }^{25}$ We acknowledge that firms often take write-offs around major corporate control events. This makes it hard to compare operating performance before and after the integration activities.

${ }^{26}$ When calculating asset-weighted industry performance for a sample exchange, we do not include that sample exchange.

${ }^{27}$ When we use equal-weighted industry average accounting performance, we obtain the similar results. The results are not reported here, but are available upon request.

${ }^{28}$ A copy of the test results associated with all the performance metrics is available from the author upon request. See Barber and Lyon (1996) for more details of various measures of performance and statistical tests used to detect abnormal operating performance.
} 
to examine which characteristics contribute to improving exchanges' long-run accounting performance. The model specification is as follows:

$$
\begin{aligned}
& \text { ChangeofPerfromance }=\alpha+\beta_{1} \text { DealCharacteristics }+\beta_{2} \text { LearningByDoing }+\beta_{3} \\
& \text { ExchangeCharactistics }+\beta_{4} \text { MacroDevelopment }+\beta_{5} \text { TechnologicalIntegration }+\beta_{6} \\
& \text { DifLegalandLanguage }+\beta_{7} \text { DifMarketDevelopment }+\beta_{8} \text { DifGovernance }+\varepsilon
\end{aligned}
$$

where the dependent variable ChangeofPerformance is the difference in industryadjusted ROA or ROE for integration $i$ between the year +2 and the year -2 . The results are reported in Table 10. First, the performance increases more when the deal is a stock exchange M\&A compared with a joint venture or an alliance. Second, horizontal (crossborder) stock exchange integration activities increase performance more for the stock exchange than vertical (domestic) ones. Finally, the better the shareholder protection, accounting standards, and capital market development in the partner's country, the better accounting ratio performance for the stock exchange. These patterns are consistent with the results when we investigate exchanges' short-run and long-run abnormal return.

The exchange accounting performance are mainly driven by the revenue from trading and IPOs. Thus, we examine the pattern in liquidity and IPO after the announcement of integration activities. We obtain the data from the website of World Exchange Federation. The exchange liquidity is measured as the value of share trading divided by market capitalization of listed stocks. The exchange IPOs is measured as the market capitalization of IPOs divided by market capitalization of listed stocks. Similar to industry-adjusted accounting performance measures, we construct two variables: 
industry-adjusted liquidity and industry-adjusted IPOs and do a multivariate analysis. As shown in Table 11, we obtain similar results compared with those we obtain when we examine the accounting performance.

\subsection{Robustness tests}

To make sure our results are not driven by a specific model, we examine another model based on Jin and Myers (2006) incorporating lagged market returns to avoid the influence of nonsynchronous trading. We use different event windows, i.e. $[-2,2]$ and $[-3$, 3] to calculate abnormal return. We also calculate heteroskedasticity robust t-statistics by regressing $C A R[-1,1]$ on an intercept. For the four joint venture announcements and the seven non-equity alliance announcements for which we have return data on multiple partners, we combine the returns of all partners in the same joint venture or non-equity alliance to form a value-weighted portfolio using the market values of the partner firms on event day - 31 as weights. We then treat the portfolio as a single observation in conducting our event study. By combining the returns of partner firms in a given nonequity alliance, we avoid the problem of a lack of independence in sample observations because there may be a correlation in the partner firms' returns. These procedures do not qualitatively change our findings. ${ }^{29}$

\section{Summary and conclusions}

We provide evidence concerning the impact of M\&As and strategic alliances on the wealth of the partnering stock exchanges' shareholders. We find significant positive wealth effects, on average, from the formation of such M\&As and alliances. These results

\footnotetext{
${ }^{29}$ The results are available upon request, although not reported.
} 
support the conjecture that global exchange integration activities may well promote the efficiency of cross-border capital flows and increased governance standards, and thus have the potential to create value for their shareholders. We acknowledge that the consolidation of exchanges may reduce competition and opportunities for cross-listings in the future. Thus, the loss to future consumers should be properly deducted from the benefit to current shareholders.

We also find that stock exchange alliances lead to the creation of less value for both partner firms than joint ventures. Similarly, less value accrues through stock exchange joint ventures compared with M\&As. By examining what types of stock exchange integration activities have the greatest wealth impact on the partnering exchanges, we find that horizontal integration activities tend to produce larger wealth effects than vertical ones. In addition, cross-border integration activities tend to produce larger wealth effects than domestic ones. Additionally, there is evidence of learning-bydoing in stock exchange integration activities. Finally, we find that the better the shareholder protection, accounting standards and capital market development in the partner exchange's country, the higher the merger and alliance premium for our sample exchange. These patterns are consistent when we examine the long-run performance measures such as the three-year buy-and-hold abnormal return, the change in ROA (ROE), the change in liquidity and the change in market capitalization of IPO between the year +2 and the year -2 .

The results of this paper may prove to be instructive for managers of stock exchanges. In general, the use of M\&As and alliances by stock exchanges creates value for their shareholders. Furthermore, expanding horizontally into international markets 
provides stock exchanges with the opportunity to capitalize on their domestic expertise and reap handsome profits. The paper may also guide investors to value stock exchange shares. 


\section{References}

Aggarwal, R. (2002), "Demutualization and Corporate Governance of Stock Exchanges", Journal of Applied Corporate Finance 15(1), pp. 105-113..

Amihud, Y., and L. H. Mendelson (1986), "Asset Pricing and the Bid-ask Spread", Journal of Financial Economics 17, pp. 223-249.

Anand, B.N., and Khanna, T. (2000), "Do Firms Learn to Create Value? The Case of Alliances", Strategic Management Journal 21, pp. 295-315.

Arnold, T., P. Hersch, J. H. Mulherin and J. Netter (1999), "Merging Markets", Journal of Finance 52, pp. 655-681.

Arrow, Kenneth (1962), “The Economic Implications of Learning By Doing”, Review of Economic Studies 29(3), pp. 155-173.

Barber, B., and J. Lyon (1996), "Detecting Abnormal Operating Performance: The Empirical Power and Specification of Test-statistics", Journal of Financial Economics 3, pp. 359-400.

Bhagat, S., A. Shleifer and R. Vishny (1990), "Hostile Takeovers in the 1980s: The Return to Corporate Specialization", in Brookings Papers on Economic Activity, Brookings Institution, Washington, DC, pp. 1-72.

Brennan, M. J., and A. Subrahmanyam (1996), "Market Microstructure and Asset Pricing: On the Compensation for Illiquidity in Stock Returns", Journal of Financial Economics 41, pp. 441-464.

Chan, S. H., J. W. Kensinger, A. J. Keown and J. D. Martin (1997), "Do Strategic Alliances Create Value?”, Journal of Financial Economics 45(2),pp.199-221.

Chang, S. (1998), "Takeovers of Privately Held Targets, Methods of Payment, and Bidder Returns", Journal of Finance 53(2), pp.773-784.

Datar, V., N. Naik and R. Radcliffe (1998), "Liquidity and Stock Returns: an Alternative Test”, Journal of Financial Markets 1(2), pp. 203-219.

DeLong, G. L. (2001), “Stockholder Gains from Focusing Versus Diversifying Bank Mergers", Journal of Financial Economics 59, pp. 221-252. 
DeLong, G. L. and R. Deyound (2007), "learning by Observing: Information Spillovers in the Execution and Valuation of Commercial Bank M\&As", Journal of Finance 62(1), pp. 181-215.

Dessein, W. (2005), "Information and Control in Ventures and Alliances", Journal of Finance, 65(5), pp. 2513-2549.

Frost, C. A., E. A. Gordon, and A. F. Hayes (2006), "Stock Exchange Disclosure and Market Development: An Analysis of 50 International Exchanges", Journal of Accounting Research 44(3), pp. 437-493.

Ghemawat, P. (1985), "Building Strategy on the Experience Curve", Harvard Business Review March-April, pp. 143-149.

Gomes-Casseres, B., J. Hagedoorn, and A. B. Jaffe (2006), "Do Alliances Promote Knowledge Flows?" Journal of Financial Economics 80, pp. 5-33.

Hartler, K. and W. Corcoran (1978), "The Time-cost trade-off for airlines", Journal of Industrial Economics 26, pp. 209-222.

Hasan, I., and M. Malkamäki (2001), "Are Expansions Cost Effective for Stock Exchanges? A Global Perspective”, Journal of Banking and Finance 25, pp. 23392366.

Hasan, I., M. Malkamäki and H. Schmiedel (2003), "Technology, Automation and Productivity of Stock Exchanges: International Evidence", Journal of Banking and Finance 27, pp. 1743-1773.

Jensen, M. (1986a), "Agency Cost of Free Cash Flow, Corporate Finance, and Takeovers", American Economic Review 76, pp. 323-329.

Jensen, M. (1986b), “The Takeover Controversy: Analysis and Evidence", Midland Corporate Finance Journal 4, pp. 6-32.

Jin, L., and S. C. Myers (2006), "R ${ }^{2}$ around the World: New Theory and New Tests", Journal of Financial Economics 79, pp. 257-292.

Kaplan, S., and M. Weisbach (1992), "The Success of Acquisitions: Evidence from Divestitures", Journal of Finance 47, pp. 107-138.

Knowledge@Wharton (2006), “LSE, NYSE, OMX, Nasdaq, Euronext ... Why Stock Exchanges Are Scrambling to Consolidate", Written Statement. (http://knowledge.wharton.upenn.edu/article.cfm?articleid=1428) 
Krishnamurti, C., J. M. Sequeira, and F. Fangjian (2003), "Stock Exchange Governance and Market Quality”, Journal of Banking and Finance 27, pp. 1859-1878.

Korajczyk, R. (1997), “A Measure of Stock Market Integration for Developed and Emerging Markets", Working Paper 197, Northwestern University.

La Porta, R., F. Lopez-de-Silanes, A. Shleifer and R. Vishny (1998), “Law and Finance”, Journal of Political Economy 54, pp. 471-517.

Mackinlay, A. C. (1997), "Event Studies in Economics and Finance”, Journal of Economic Literature 35(1), pp. 13-39.

McConnell, J., and T. Nantell (1985), "Common Stock Returns and Corporate Combinations: The Case of Joint Ventures", Journal of Finance 40, pp. 519-536.

Mendiola, A. and M. O’Hara (2003), "Taking Stock in Stock Markets: The Changing Governance of Exchanges", Working Paper, Cornell University.

Mody, A. (1993), "Learning through Alliances", Journal of Economic Behavior and Organization 20, pp. 151-170.

O'Brien, R. (1992), “Global Financial Integration: The End of Geography”, Royal Institute of International Affairs, Chatman House, London.

Pagano, M., Röell, A., and Zechner, J. (2002), “The Geography of Equity Listing: Why Do Companies List Abroad?” The Journal of Finance, 57(6), pp. 2651 - 2694.

Pagano, M., Randl, O., Röell, A. and Zechner, J. (2001), "What Makes Stock Exchanges Succeed? Evidence from Cross-listing Decisions", European Economic Review, 45, pp. $770-82$.

Pirrong, C. (1999), "The Organization of Financial Exchange Markets: Theory and Evidence", Journal of Financial Markets 2, pp. 329-357.

Ravenscraft, D., and F. Scherer (1987), "Mergers, Sell-Offs and Economic Efficiency”, Brookings Institution, Washington, DC.

Santos, T., and J. A. Scheinkman (2001), “Competition among Exchanges”, Quarterly Journal of Economics 116, pp. 1027-1061.

Serifsoy, B. (2007), "Stock Exchange Business Models and Their Operative Performance", Journal of Banking and Finance 31, pp. 2978-3012. 
Tasi, W. (2001), “Knowledge Transfer in Intraorganizational Networks: Effects of Network Position and Absorptive Capacity on Business Unit Innovation and Performance”, Academy of Management Journal, 44(5), pp. 996-1004.

US Securities and Exchange Commission (2007), “A Global View: Examining CrossBorder Exchange Mergers", Written Statement.

Williamson, O. (1979), "Transaction Cost Economics: The Governance of Contractual Relations", Journal of Law and Economics 22, pp. 233-261. 
Figure 1 Cumulative return around announcement of stock exchange M\&A, joint venture and non-equity alliance

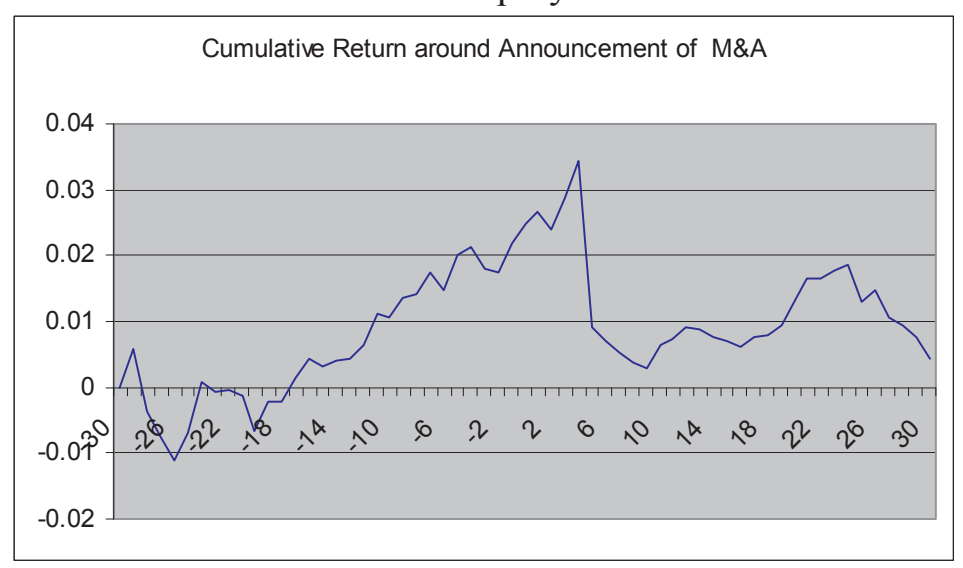

Panel A

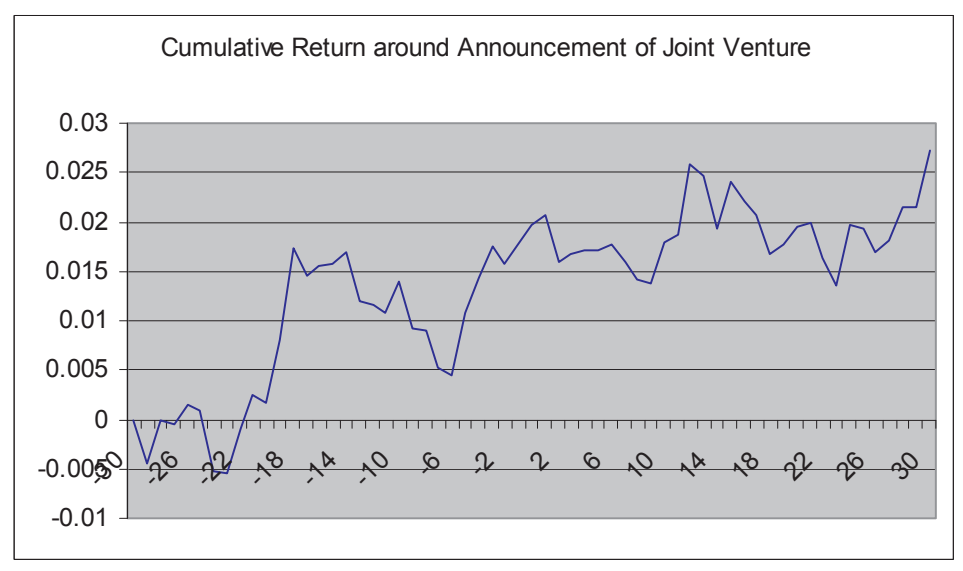

Panel B

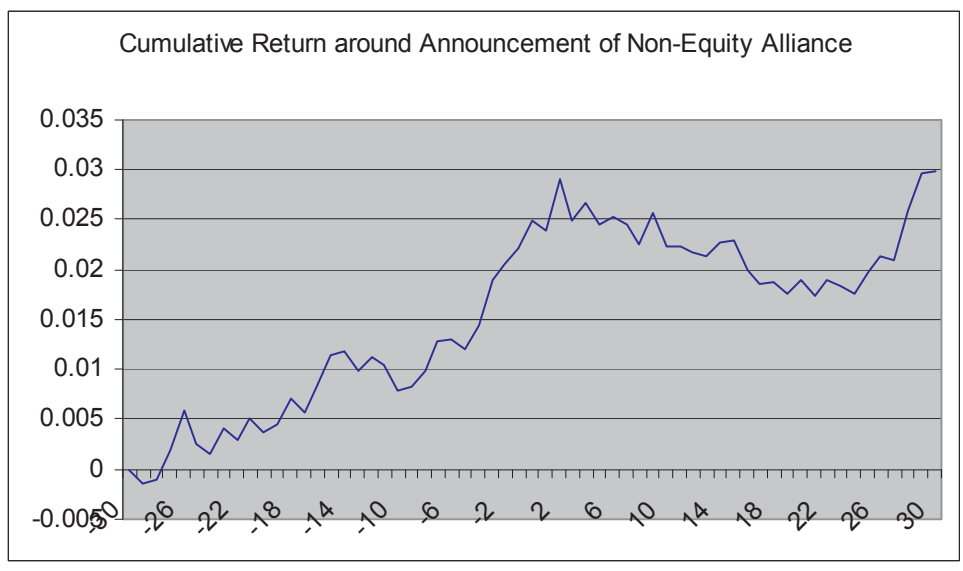

Panel C 


\section{Table 1 Public stock exchange in our sample}

This table describes 14 public stock exchange companies in our sample, the country in which their headquarters are located, the stock exchanges in which they are listed and the Datastream code for their stocks.

\begin{tabular}{|c|c|c|c|c|}
\hline No. & Public stock exchange company & $\begin{array}{l}\text { Country in which its } \\
\text { headquarter is located }\end{array}$ & Stock exchange in which it is listed & $\begin{array}{l}\text { Datastream code } \\
\text { for its stock }\end{array}$ \\
\hline 1 & Australian securities exchange & Australia & Australian securities exchange & 675705 \\
\hline 2 & Chicago board of trade & United States & New York stock exchange & $30965 \mathrm{P}$ \\
\hline 3 & Chicago mercantile exchange & United States & NASDAQ & $26393 \mathrm{~N}$ \\
\hline 4 & Deutsche Boerse & Germany & Frankfurt stock exchange & $13454 \mathrm{U}$ \\
\hline 5 & Euronext & France & Paris bourse & 259413 \\
\hline 6 & Hong Kong stock exchange & Hong Kong (China) & Hong Kong stock exchange & 280037 \\
\hline 7 & London stock exchange & United Kingdom & London stock exchange & 298593 \\
\hline 8 & NASDAQ & United States & NASDAQ & $25735 \mathrm{~K}$ \\
\hline 9 & New York stock exchange & United States & New York stock exchange & $28560 \mathrm{~F}$ \\
\hline 10 & OMX exchanges & Sweden & Stockholm exchange & 504592 \\
\hline 11 & Osaka securities exchange & Japan & Osaka securities exchange & $28545 \mathrm{H}$ \\
\hline 12 & Sao Paulo stock exchange & Brazil & Sao Paulo stock exchange & $51216 \mathrm{~L}$ \\
\hline 13 & Singapore exchange & Singapore & Singapore exchange & 280738 \\
\hline 14 & TSX group & Canada & Toronto exchange & $26492 \mathrm{~L}$ \\
\hline
\end{tabular}


Table 2 Announcements of stock exchange M\&As and alliances

This table presents the sample distributions by year and type of integrations.

\begin{tabular}{|c|c|c|}
\hline Year of announcement & Number of announcements & Percentage of total \\
\hline 2000 & 5 & 4.55 \\
\hline 2001 & 8 & 7.27 \\
\hline 2002 & 8 & 7.27 \\
\hline 2003 & 12 & 10.91 \\
\hline 2004 & 13 & 11.82 \\
\hline 2005 & 14 & 12.73 \\
\hline 2006 & 20 & 18.18 \\
\hline 2007 & 28 & 25.45 \\
\hline 2008 & 2 & 1.82 \\
\hline Total & 110 & 100 \\
\hline \multicolumn{3}{|c|}{ Panel A: Annual distribution of stock exchange integration activities } \\
\hline Type of integration activities & Number of announcements & Percentage of total \\
\hline Horizontal & 93 & 84.55 \\
\hline Vertical & 17 & 15.45 \\
\hline Cross-border & 99 & 90.00 \\
\hline Domestic & 11 & 10.00 \\
\hline \multicolumn{3}{|c|}{ Panel B: Distribution of stock exchange integration activities by type } \\
\hline Type of technological integration & Number of announcements & Percentage of total \\
\hline Outsourcing & 17 & 15.45 \\
\hline Common access & 9 & 8.18 \\
\hline Common systems & 5 & 4.55 \\
\hline Common operation & 6 & 5.45 \\
\hline Complete system integration & 16 & 14.55 \\
\hline Other type of integration & 55 & 50.00 \\
\hline
\end{tabular}

Panel C: Distribution of stock exchange integration activities by type of technological integration 
Table 3 Summary statistics

This table presents the summary statistics. Performance measures and exchange characteristics are winsorized at the $1^{\text {st }}$ and $99^{\text {th }}$ percentiles. Variable definitions are given in Appendix B.

\begin{tabular}{|c|c|c|c|c|c|}
\hline Variable & Obs & Mean & Std. Dev. & Min & Max \\
\hline CAR $[-1,1](\%)$ & 121 & 1.08 & 0.33 & -5.96 & 6.48 \\
\hline $\mathrm{BHAR}_{1,36}(\%)$ & 70 & 97.37 & 26.45 & -66.56 & 212.44 \\
\hline Difference in industry-adjusted ROE between the year +2 and the year $-2(\%)$ & 52 & 7.89 & 2.45 & -4.93 & 16.52 \\
\hline Difference in industry-adjusted ROA between the year +2 and the year $-2(\%)$ & 60 & 3.25 & 0.81 & -2.47 & 8.01 \\
\hline Difference in industry-adjusted exchange liquidity between the year +2 and the year $-2(\%)$ & 58 & 0.12 & 0.04 & -0.15 & 0.27 \\
\hline Difference in industry-adjusted exchange IPO between the year +2 and the year $-2(\%)$ & 58 & 0.11 & 0.03 & -0.13 & 0.28 \\
\hline \multicolumn{6}{|l|}{ Panel A: Exchange performance measures } \\
\hline InterType & 121 & 1.36 & 0.87 & 0.00 & 3.00 \\
\hline Horizontal & 121 & 0.82 & 0.39 & 0.00 & 1.00 \\
\hline CrossBorder & 121 & 0.89 & 0.31 & 0.00 & 1.00 \\
\hline Public & 121 & 0.12 & 0.31 & 0.00 & 1.00 \\
\hline \multicolumn{6}{|l|}{ Panel B: Deal characteristics } \\
\hline NoPreMA & 121 & 1.21 & 1.73 & 0.00 & 6.00 \\
\hline NoPreJV & 121 & 0.54 & 0.85 & 0.00 & 3.00 \\
\hline NoPreAL & 121 & 3.08 & 2.76 & 0.00 & 11.00 \\
\hline \multicolumn{6}{|l|}{ Panel C: Learning-by-doing variables } \\
\hline MarketValue (\$ millions) & 121 & $4,045.91$ & $5,841.73$ & 12.86 & $34,753.22$ \\
\hline TotalAssets (\$ millions) & 116 & $7,292.16$ & $14,817.00$ & 30.70 & $60,535.95$ \\
\hline CashFlow & 116 & 0.11 & 0.10 & 0.01 & 0.41 \\
\hline Leverage & 112 & 0.59 & 0.17 & 0.39 & 0.79 \\
\hline $\mathrm{Q}$ & 112 & 2.74 & 2.07 & 1.11 & 8.66 \\
\hline \multicolumn{6}{|l|}{ Panel D: Exchange characteristics } \\
\hline GDPPerCapita (\$) & 91 & $25,867.41$ & $8,831.08$ & 949.18 & $39,824.08$ \\
\hline GDPGrowth (\%) & 91 & 2.99 & 2.41 & -2.40 & 10.00 \\
\hline \multicolumn{6}{|l|}{ Panel E: Difference in language and legal system } \\
\hline SameLanguage & 121 & 0.54 & 0.22 & 0.00 & 1.00 \\
\hline SameLegalSystem & 121 & 0.33 & 0.21 & 0.00 & 1.00 \\
\hline \multicolumn{6}{|l|}{ Panel F: Macroeconomic development variables } \\
\hline DifMarketToGDP (\%) & 91 & 0.18 & 0.77 & -2.62 & 2.43 \\
\hline DifTurnOver (\%) & 90 & 0.20 & 0.58 & -1.54 & 1.59 \\
\hline DifStockTradeToGDP (\%) & 91 & 0.28 & 0.90 & -2.52 & 1.91 \\
\hline \multicolumn{6}{|l|}{ Panel G: Difference in capital market development } \\
\hline DifShareholderProtection & 75 & 2.79 & 20.68 & -41.00 & 50.00 \\
\hline DifAccountingStandards & 71 & 4.66 & 13.41 & -21.00 & 59.00 \\
\hline
\end{tabular}

Panel H: Difference in governance 
Table 4 Cumulative return $[-1,1]$ around announcement of stock exchange M\&A, joint venture and non-equity alliance

This table presents the results of the event study in different subsamples. *, ** and *** stand for significance at the $10 \%, 5 \%$ and $1 \%$ levels.

\begin{tabular}{cccc}
\hline Event type & $\begin{array}{c}\text { Number of } \\
\text { observations }\end{array}$ & CAR [-1, 1] (\%) & Proportion of positive \\
value (sign test)
\end{tabular}

Panel A: Announcement period cumulative return [-1,1]

\begin{tabular}{|c|c|c|c|c|}
\hline Two group of events & $\begin{array}{c}\text { Number of } \\
\text { observations }\end{array}$ & Difference of CAR $[-1,1](\%)$ & T-statistic & $\begin{array}{c}\text { P value (Wilcoxon } \\
\text { rank-sum test) }\end{array}$ \\
\hline M\&A and joint venture & 50 & 0.33 & $4.42 * * *$ & $0.01 * * *$ \\
\hline M\&A and non-equity alliance & 101 & 0.44 & $4.56^{* * *}$ & $0.03 * *$ \\
\hline Joint venture and non-equity alliance & 91 & 0.11 & $4.28 * * *$ & $0.01 * * *$ \\
\hline
\end{tabular}

Panel B: Comparison of announcement period cumulative return [-1,1] among $M \& A$, joint ventures, and non-equity alliances 
Table 5 Cumulative return $[-1,1]$ around announcement of stock exchange M\&A, joint venture and non-equity alliance in sub-sample

This table presents the results of the event study in different subsamples. *,** and *** stand for significance at the $10 \%, 5 \%$ and $1 \%$ levels.

\begin{tabular}{|c|c|c|c|c|}
\hline Event type & $\begin{array}{c}\text { Number of } \\
\text { observations }\end{array}$ & CAR $[-1,1](\%)$ & Z-statistic & $\begin{array}{c}\text { Proportion of positive value } \\
\text { (sign test) }\end{array}$ \\
\hline Cross-border M\&A & 23 & 2.00 & $3.05 * * *$ & $78 \% * *$ \\
\hline Domestic M\&A & 7 & -0.59 & -0.37 & $57 \%$ \\
\hline Cross-border joint venture & 19 & 1.13 & $2.62 * * *$ & $74 \% *$ \\
\hline Cross-border non-equity alliance & 66 & 1.3 & $3.92 * * *$ & $71 \% * * *$ \\
\hline Domestic non-equity alliance & 5 & -3.7 & -2.21 & $40 \%$ \\
\hline
\end{tabular}

Panel A: Comparison of announcement period cumulative return $[-1,1]$ between cross-border and domestic deals

\begin{tabular}{|c|c|c|c|c|}
\hline Event type & $\begin{array}{c}\text { Number of } \\
\text { observations }\end{array}$ & CAR $[-1,1](\%)$ & Z-statistic & $\begin{array}{c}\text { Proportion of positive value } \\
\text { (sign test) }\end{array}$ \\
\hline Horizontal M\&A & 22 & 1.88 & $2.66^{* * *}$ & $77 \% * *$ \\
\hline Horizontal joint venture & 15 & 1.24 & $2.82 * * *$ & $73 \% *$ \\
\hline Horizontal non-equity alliance & 62 & 1.1 & $3.47 * * *$ & $69 \% * * *$ \\
\hline Vertical non-equity alliance & 9 & -0.6 & -0.51 & $66 \%$ \\
\hline
\end{tabular}

Panel B: Comparison of announcement period cumulative return $[-1,1]$ between horizontal and vertical deals

\begin{tabular}{ccccc}
\hline Exchange type & $\begin{array}{c}\text { Number of } \\
\text { observations }\end{array}$ & CAR [-1, 1] (\%) & Z-statistic & $\begin{array}{c}\text { Proportion of positive value } \\
\text { (sign test) }\end{array}$ \\
\hline Acquirer exchange & 6 & -2.76 & $-3.78 * * *$ & $0 \% * * *$ \\
Target exchange & 5 & 0.14 & 0.03 & $25 \%$ \\
\hline
\end{tabular}

Panel C: Analysis of failed $M \& A$ deals

\begin{tabular}{|c|c|c|c|c|c|}
\hline Exchange type & $\begin{array}{c}\text { Number of } \\
\text { observations }\end{array}$ & CAR $[-1,1](\%)$ & Z-statistic & $\begin{array}{c}\text { Mean market } \\
\text { value (\$m.) }\end{array}$ & $\begin{array}{c}\text { Mean change in } \\
\text { wealth }(\$ \mathrm{~m} .)\end{array}$ \\
\hline Acquirer exchange & 3 & 0.90 & $4.33 * * *$ & $4,022.33$ & 36.20 \\
\hline Target exchange & 3 & 2.83 & $4.55 * * *$ & $1,065.45$ & 30.15 \\
\hline Lager joint venture partner & 4 & 0.21 & 0.99 & $3,300.12$ & 6.93 \\
\hline Smaller joint venture partner & 4 & 2.55 & $6.33 * * *$ & 280.54 & 7.15 \\
\hline Larger alliance partner & 7 & 0.18 & 1.05 & $3,046.41$ & 5.48 \\
\hline Smaller alliance partner & 7 & 2.23 & $6.12 * * *$ & 230.82 & 5.15 \\
\hline
\end{tabular}

Panel D: Analysis of wealth effects by relative partner size 


\section{Table 6 Cross-sectional analysis of CARs upon announcement}

The dependent variable is the three-day cumulative abnormal return (CAR) in percentage points. Variable definitions are given in Appendix B. In brackets are t-statistics based on standard errors adjusted for heteroskedasticity and country clustering. $*, * *$ and $* * *$ stand for significance at the $10 \%, 5 \%$ and $1 \%$ level respectively.

\begin{tabular}{|c|c|c|c|c|}
\hline \multirow[t]{2}{*}{ Dependent variable } & \multicolumn{4}{|c|}{$\operatorname{CAR}[-1,1]$} \\
\hline & (1) & (2) & (3) & (4) \\
\hline \multicolumn{5}{|l|}{ Deal characteristics } \\
\hline \multirow{2}{*}{ InterType } & $-0.674 *$ & $-0.598 * * *$ & $-0.550 * * *$ & $-1.101 * *$ \\
\hline & $(-1.761)$ & $(-4.493)$ & $(-4.389)$ & $(-2.015)$ \\
\hline \multirow[t]{2}{*}{ Horizontal } & $2.819^{* *}$ & $2.800 * *$ & $2.463^{*}$ & $3.072^{*}$ \\
\hline & $(2.270)$ & $(2.227)$ & $(1.802)$ & $(1.930)$ \\
\hline \multirow[t]{2}{*}{ CrossBorder } & $2.362^{* *}$ & $2.376^{* *}$ & $2.028^{* * *}$ & $2.149 * * *$ \\
\hline & $(2.069)$ & $(2.006)$ & $(3.499)$ & $(3.185)$ \\
\hline \multirow[t]{2}{*}{ Public } & 0.002 & 0.006 & 0.003 & 0.003 \\
\hline & $(0.005)$ & $(0.007)$ & $(0.004)$ & $(0.009)$ \\
\hline \multicolumn{5}{|l|}{ Leaning-by-doing variables } \\
\hline \multirow[t]{2}{*}{ NoPreMA } & & $0.012 * * *$ & $0.024 * * *$ & $0.019^{* * *}$ \\
\hline & & $(4.684)$ & $(3.359)$ & $(3.259)$ \\
\hline \multirow[t]{2}{*}{ NoPreJV } & & $0.010^{* * *}$ & $0.017 * * *$ & $0.031 * * *$ \\
\hline & & (4.019) & $(4.499)$ & $(4.715)$ \\
\hline \multirow[t]{2}{*}{ NoPreAL } & & $0.014 * * *$ & $0.019 * * *$ & $0.023^{* * *}$ \\
\hline & & $(5.563)$ & $(4.379)$ & $(4.629)$ \\
\hline \multicolumn{5}{|l|}{ Exchange characteristics } \\
\hline \multirow[t]{2}{*}{ Log(TotalAssets) } & & & $-0.647^{*}$ & $-0.369^{* * *}$ \\
\hline & & & $(-1.853)$ & $(-4.653)$ \\
\hline \multirow[t]{2}{*}{ Q } & & & 0.337 & 0.053 \\
\hline & & & $(1.310)$ & $(0.145)$ \\
\hline \multirow[t]{2}{*}{ Leverage } & & & -3.131 & -0.166 \\
\hline & & & $(-1.269)$ & $(-0.034)$ \\
\hline \multirow{2}{*}{ CashFlow } & & & 0.021 & 0.076 \\
\hline & & & $(0.378)$ & $(1.057)$ \\
\hline \multicolumn{5}{|l|}{ Macroeconomic variables } \\
\hline \multirow[t]{2}{*}{ Log(GDPPerCapita) } & & & & -1.029 \\
\hline & & & & $(-1.556)$ \\
\hline \multirow[t]{2}{*}{ Log(GDPGrowth) } & & & & 0.336 \\
\hline & & & & $(0.578)$ \\
\hline \multicolumn{5}{|l|}{ Control for } \\
\hline Technological integration dummy variables & Yes & Yes & Yes & Yes \\
\hline Difference in language and legal environment & Yes & Yes & Yes & Yes \\
\hline Country effect & Yes & Yes & Yes & Yes \\
\hline Year effect & Yes & Yes & Yes & Yes \\
\hline Adjusted R-squared & 0.14 & 0.12 & 0.16 & 0.19 \\
\hline No. of observations & 121 & 121 & 112 & 83 \\
\hline
\end{tabular}


Table 7 Cross-sectional analysis of CARs upon announcement controlling for the difference in capital market development

The dependent variable is the three-day cumulative abnormal return (CAR) in percentage points. Variable definitions are given in Appendix B. In brackets are t-statistics based on standard errors adjusted for heteroskedasticity and country clustering. $*, * *$ and $* * *$ stand for significance at the $10 \%, 5 \%$ and $1 \%$ level respectively.

\begin{tabular}{|c|c|c|c|}
\hline \multirow[t]{2}{*}{ Dependent variable } & \multicolumn{3}{|c|}{ CAR $[-1,1]$} \\
\hline & (1) & (2) & (3) \\
\hline \multicolumn{4}{|l|}{ Deal characteristics } \\
\hline \multirow[t]{2}{*}{ InterType } & $-1.135^{*}$ & $-1.136^{* *}$ & $-1.092 *$ \\
\hline & $(-1.996)$ & $(-2.017)$ & $(-1.979)$ \\
\hline \multirow[t]{2}{*}{ Horizontal } & $3.127 *$ & $3.081 *$ & $3.055^{*}$ \\
\hline & $(1.935)$ & $(1.891)$ & $(1.904)$ \\
\hline \multirow[t]{2}{*}{ CrossBorder } & $2.099 * * *$ & $2.129 * * *$ & $2.179 * * *$ \\
\hline & $(4.135)$ & $(4.189)$ & $(4.199)$ \\
\hline \multirow[t]{2}{*}{ Public } & 0.002 & 0.002 & 0.004 \\
\hline & $(0.004)$ & $(0.005)$ & $(0.007)$ \\
\hline \multicolumn{4}{|l|}{ Leaning-by-doing variables } \\
\hline \multirow[t]{2}{*}{ NoPreMA } & $0.021 * * *$ & $0.014 * * *$ & $0.015 * * *$ \\
\hline & $(4.184)$ & $(5.208)$ & $(4.271)$ \\
\hline \multirow[t]{2}{*}{ NoPreJV } & $0.016^{* * *}$ & $0.019 * * *$ & $0.014 * * *$ \\
\hline & $(4.739)$ & $(4.789)$ & $(4.703)$ \\
\hline \multirow[t]{2}{*}{ NoPreAL } & $0.014 * * *$ & $0.022 * * *$ & $0.013 * * *$ \\
\hline & $(4.646)$ & $(4.634)$ & $(3.890)$ \\
\hline \multicolumn{4}{|l|}{ Difference in capital market development } \\
\hline \multirow[t]{2}{*}{ DifMarketToGDP } & $-0.169 * * *$ & & \\
\hline & $(-4.289)$ & & \\
\hline \multirow[t]{2}{*}{ DifTurnover } & & $-0.161 * * *$ & \\
\hline & & $(-5.178)$ & \\
\hline \multirow[t]{2}{*}{ DifStockTradeToGDP } & & & $-0.073 * * *$ \\
\hline & & & $(-4.146)$ \\
\hline \multicolumn{4}{|l|}{ Control for } \\
\hline Exchange characteristics & Yes & Yes & Yes \\
\hline Macroeconomic variables & Yes & Yes & Yes \\
\hline Technological integration dummy variables & Yes & Yes & Yes \\
\hline Difference in language and legal environment & Yes & Yes & Yes \\
\hline Country effect & Yes & Yes & Yes \\
\hline Year effect & Yes & Yes & Yes \\
\hline Adjusted R-squared & 0.19 & 0.20 & 0.20 \\
\hline No. of observations & 83 & 81 & 83 \\
\hline
\end{tabular}


Table 8 Cross-sectional analysis of CARs upon announcement controlling for the difference in governance

The dependent variable is the three-day cumulative abnormal return (CAR) in percentage points. Variable definitions are given in Appendix B. In brackets are t-statistics based on standard errors adjusted for heteroskedasticity and country clustering. $*, * *$ and $* * *$ stand for significance at the $10 \%, 5 \%$ and $1 \%$ level respectively.

\begin{tabular}{|c|c|c|}
\hline \multirow[t]{2}{*}{ Dependent variable } & \multicolumn{2}{|c|}{ CAR $[-1,1]$} \\
\hline & (1) & $(2)$ \\
\hline \multicolumn{3}{|l|}{ Deal characteristics } \\
\hline \multirow[t]{2}{*}{ InterType } & $-0.942 * * *$ & $-1.033 * * *$ \\
\hline & $(-4.237)$ & $(-4.459)$ \\
\hline \multirow[t]{2}{*}{ Horizontal } & $1.914 * * *$ & $2.435^{* * *}$ \\
\hline & $(5.034)$ & $(4.468)$ \\
\hline \multirow[t]{2}{*}{ CrossBorder } & $1.844 * * *$ & $2.107 * * *$ \\
\hline & $(5.980)$ & $(4.224)$ \\
\hline \multirow[t]{2}{*}{ Public } & 0.004 & 0.002 \\
\hline & $(0.006)$ & $(0.008)$ \\
\hline \multicolumn{3}{|l|}{ Leaning-by-doing variables } \\
\hline \multirow[t]{2}{*}{ NoPreMA } & $0.019 * * *$ & $0.013 * * *$ \\
\hline & $(4.601)$ & $(4.423)$ \\
\hline \multirow{2}{*}{ NoPreJV } & $0.017 * * *$ & $0.019 * * *$ \\
\hline & $(4.033)$ & $(4.089)$ \\
\hline \multirow[t]{2}{*}{ NoPreAL } & $0.013^{* * *}$ & $0.023 * * *$ \\
\hline & $(4.688)$ & $(4.389)$ \\
\hline \multicolumn{3}{|l|}{ Difference in capital market development } \\
\hline \multirow[t]{2}{*}{ DifTurnover } & $-0.057^{* * *}$ & $-0.045^{* * *}$ \\
\hline & $(-4.067)$ & $(-4.398)$ \\
\hline \multicolumn{3}{|l|}{ Difference in governance } \\
\hline \multirow[t]{2}{*}{ DifShareholderProtection } & $-0.028 * * *$ & \\
\hline & $(-3.931)$ & \\
\hline \multirow[t]{2}{*}{ DifAccountingStandards } & & $-0.135^{* * *}$ \\
\hline & & $(-2.799)$ \\
\hline \multicolumn{3}{|l|}{ Control for } \\
\hline Exchange characteristics & Yes & Yes \\
\hline Macroeconomic variables & Yes & Yes \\
\hline Technological integration dummy variables & Yes & Yes \\
\hline Difference in language and legal environment & Yes & Yes \\
\hline Country effect & Yes & Yes \\
\hline Year effect & Yes & Yes \\
\hline Adjusted R-squared & 0.21 & 0.22 \\
\hline No. of observations & 54 & 51 \\
\hline
\end{tabular}


Table 9 Cross-sectional analysis of three-year BHARs

The dependent variable is the three-year buy-and-hold abnormal return (BHAR). Variable definitions are given in Appendix B. In brackets are t-statistics based on standard errors adjusted for heteroskedasticity and country clustering. $*, * *$ and $* * *$ stand for significance at the $10 \%, 5 \%$ and $1 \%$ level respectively.

\begin{tabular}{|c|c|c|}
\hline \multirow[t]{2}{*}{ Dependent variable } & \multicolumn{2}{|c|}{$\operatorname{BHAR}_{(1,36)}$} \\
\hline & (1) & (2) \\
\hline \multicolumn{3}{|l|}{ Deal characteristics } \\
\hline \multirow[t]{2}{*}{ InterType } & $-3.823^{* * *}$ & $-3.316^{* * *}$ \\
\hline & $(-4.289)$ & $(-5.855)$ \\
\hline \multirow[t]{2}{*}{ Horizontal } & $8.145^{* * *}$ & $16.679 * * *$ \\
\hline & $(4.178)$ & $(5.135)$ \\
\hline \multirow[t]{2}{*}{ CrossBorder } & $3.835^{* * *}$ & $3.465^{* * *}$ \\
\hline & $(4.389)$ & $(4.289)$ \\
\hline \multirow[t]{2}{*}{ Public } & 0.013 & 0.015 \\
\hline & $(0.005)$ & $(0.009)$ \\
\hline \multicolumn{3}{|l|}{ Leaning-by-doing variables } \\
\hline \multirow[t]{2}{*}{ NoPreMA } & $1.186^{* * *}$ & $1.435^{* * *}$ \\
\hline & $(4.688)$ & $(5.455)$ \\
\hline \multirow[t]{2}{*}{ NoPreJV } & $1.102^{* * *}$ & $1.136^{* * *}$ \\
\hline & $(4.299)$ & $(4.357)$ \\
\hline \multirow[t]{2}{*}{ NoPreAL } & $1.166^{* * *}$ & $1.176^{* * *}$ \\
\hline & $(4.279)$ & $(5.156)$ \\
\hline \multicolumn{3}{|l|}{ Difference in capital market development } \\
\hline \multirow{2}{*}{ DifTurnover } & & $-1.206^{* * *}$ \\
\hline & & $(-4.198)$ \\
\hline \multicolumn{3}{|l|}{ Difference in governance } \\
\hline \multirow[t]{2}{*}{ DifShareholderProtection } & & $-1.146^{* * *}$ \\
\hline & & $(-4.556)$ \\
\hline \multicolumn{3}{|l|}{ Control for } \\
\hline Exchange characteristics & No & Yes \\
\hline Macroeconomic variables & No & Yes \\
\hline Technological integration dummy variables & Yes & Yes \\
\hline Difference in language and legal environment & Yes & Yes \\
\hline Country effect & Yes & Yes \\
\hline Year effect & Yes & Yes \\
\hline Adjusted R-squared & 0.19 & 0.42 \\
\hline No. of observations & 70 & 40 \\
\hline
\end{tabular}




\section{Table 10 Cross-sectional analysis of exchange accounting performance}

The dependent variable is the difference in the industry-adjusted ROA or the industry-adjusted ROE between the year +2 and the year -2 . Variable definitions are given in Appendix B. In brackets are tstatistics based on standard errors adjusted for heteroskedasticity and country clustering. *, ** and *** stand for significance at the $10 \%, 5 \%$ and $1 \%$ level respectively.

\begin{tabular}{|c|c|c|c|c|}
\hline \multirow[t]{2}{*}{ Dependent variable } & \multicolumn{2}{|c|}{$\begin{array}{l}\text { Difference in industry-adjusted ROA } \\
\text { between the year }+2 \text { and the year }-2\end{array}$} & \multicolumn{2}{|c|}{$\begin{array}{l}\text { Difference in industry-adjusted ROE } \\
\text { between the year }+2 \text { and the year }-2\end{array}$} \\
\hline & (1) & (2) & (3) & (4) \\
\hline \multicolumn{5}{|l|}{ Deal characteristics } \\
\hline \multirow[t]{2}{*}{ InterType } & $-0.652 * * *$ & $-0.252 * * *$ & $-1.445 * * *$ & $-0.944 * * *$ \\
\hline & $(-5.371)$ & $(-4.699)$ & $(-5.849)$ & $(-5.371)$ \\
\hline \multirow[t]{2}{*}{ Horizontal } & $1.914 * * *$ & $3.450 * * *$ & $4.951 * * *$ & $5.737 * * *$ \\
\hline & $(5.513)$ & $(6.211)$ & $(5.224)$ & $(6.321)$ \\
\hline \multirow[t]{2}{*}{ CrossBorder } & $0.520 * * *$ & $0.215^{* * *}$ & $2.261 * * *$ & $1.864 * * *$ \\
\hline & $(5.277)$ & $(6.414)$ & $(5.505)$ & $(6.069)$ \\
\hline \multirow[t]{2}{*}{ Public } & 0.006 & 0.009 & 0.012 & 0.011 \\
\hline & $(0.002)$ & $(0.007)$ & $(0.004)$ & $(0.005)$ \\
\hline \multicolumn{5}{|l|}{ Leaning-by-doing variables } \\
\hline \multirow[t]{2}{*}{ NoPreMA } & $0.062 * * *$ & $0.214^{* * *}$ & $0.027 * * *$ & $0.068 * * *$ \\
\hline & $(3.342)$ & (4.209) & $(4.296)$ & $(5.251)$ \\
\hline \multirow[t]{2}{*}{ NoPreJV } & $0.081 * * *$ & $0.015 * * *$ & $0.046^{* * * *}$ & $0.015^{* * *}$ \\
\hline & $(5.878)$ & $(4.825)$ & $(5.020)$ & $(4.804)$ \\
\hline \multirow[t]{2}{*}{ NoPreAL } & $0.043 * * *$ & $0.039 * * *$ & $0.013 * * *$ & $0.066^{* * *}$ \\
\hline & $(5.954)$ & $(4.556)$ & $(6.036)$ & $(4.256)$ \\
\hline \multicolumn{5}{|l|}{ Difference in capital market development } \\
\hline \multirow[t]{2}{*}{ DifTurnover } & & $-0.089 * * *$ & & $-0.135 * * *$ \\
\hline & & $(-4.199)$ & & $(-5.502)$ \\
\hline \multicolumn{5}{|l|}{ Difference in governance } \\
\hline \multirow[t]{2}{*}{ DifShareholderProtection } & & $-0.029 * * *$ & & $-0.106^{* * *}$ \\
\hline & & $(-4.529)$ & & $(-5.815)$ \\
\hline \multicolumn{5}{|l|}{ Control for } \\
\hline Exchange characteristics & No & Yes & No & Yes \\
\hline Macroeconomic variables & No & Yes & No & Yes \\
\hline Technological integration dummy variables & Yes & Yes & Yes & Yes \\
\hline Difference in language and legal environment & Yes & Yes & Yes & Yes \\
\hline Country effect & Yes & Yes & Yes & Yes \\
\hline Year effect & Yes & Yes & Yes & Yes \\
\hline Adjusted R-squared & 0.19 & 0.47 & 0.16 & 0.33 \\
\hline No. of observations & 60 & 34 & 52 & 33 \\
\hline
\end{tabular}


Table 11 Cross-sectional analysis of exchange liquidity and IPO

The dependent variable is the difference in the industry-adjusted exchange liquidity or the industry-adjusted exchange IPO between the year +2 and the year -2 . Variable definitions are given in Appendix B. In brackets are t-statistics based on standard errors adjusted for heteroskedasticity and country clustering. *, $* *$ and $* * *$ stand for significance at the $10 \%, 5 \%$ and $1 \%$ level respectively.

\begin{tabular}{|c|c|c|c|c|}
\hline \multirow[t]{2}{*}{ Dependent variable } & \multicolumn{2}{|c|}{$\begin{array}{c}\text { Difference in industry-adjusted } \\
\text { exchange liquidity between the year }+2 \\
\text { and the year }-2\end{array}$} & \multicolumn{2}{|c|}{$\begin{array}{l}\text { Difference in industry-adjusted } \\
\text { exchange IPO between the year }+2 \text { and } \\
\text { the year }-2\end{array}$} \\
\hline & (1) & (2) & (3) & (4) \\
\hline \multicolumn{5}{|l|}{ Deal characteristics } \\
\hline \multirow[t]{2}{*}{ InterType } & $-0.032 * * *$ & $-0.024 * * *$ & $-0.025 * * *$ & $-0.024 * * *$ \\
\hline & $(-4.234)$ & $(-4.498)$ & $(-4.367)$ & $(-4.813)$ \\
\hline \multirow[t]{2}{*}{ Horizontal } & $0.193 * * *$ & $0.325 * * *$ & $0.705 * * *$ & $0.245 * * *$ \\
\hline & $(4.893)$ & $(6.011)$ & $(4.689)$ & $(5.067)$ \\
\hline \multirow[t]{2}{*}{ CrossBorder } & $0.048^{* * *}$ & $0.025^{* * *}$ & $0.039 * * *$ & $0.018^{* * *}$ \\
\hline & $(4.145)$ & $(5.245)$ & $(4.654)$ & $(5.121)$ \\
\hline \multirow[t]{2}{*}{ Public } & 0.007 & 0.009 & 0.006 & 0.004 \\
\hline & $(0.001)$ & $(0.005)$ & $(0.004)$ & $(0.008)$ \\
\hline \multicolumn{5}{|l|}{ Leaning-by-doing variables } \\
\hline \multirow[t]{2}{*}{ NoPreMA } & $0.006^{* * *}$ & $0.024 * * *$ & $0.007 * * *$ & $0.017 * * *$ \\
\hline & $(4.392)$ & $(4.681)$ & $(4.643)$ & $(4.224)$ \\
\hline \multirow[t]{2}{*}{ NoPreJV } & $0.007 * * *$ & $0.003 * * *$ & $0.008 * * *$ & $0.004 * * *$ \\
\hline & $(5.145)$ & $(4.244)$ & $(5.876)$ & (4.133) \\
\hline \multirow[t]{2}{*}{ NoPreAL } & $0.003 * * *$ & $0.005 * * *$ & $0.002 * * *$ & $0.004 * * *$ \\
\hline & $(5.172)$ & $(4.771)$ & $(5.432)$ & (4.199) \\
\hline \multicolumn{5}{|l|}{ Difference in capital market development } \\
\hline \multirow[t]{2}{*}{ DifTurnover } & & $-0.010 * * *$ & & $-0.009 * * *$ \\
\hline & & $(-4.665)$ & & $(-4.115)$ \\
\hline \multicolumn{5}{|l|}{ Difference in governance } \\
\hline \multirow[t]{2}{*}{ DifShareholderProtection } & & $-0.006 * * *$ & & $-0.007 * * *$ \\
\hline & & $(-4.351)$ & & $(-4.135)$ \\
\hline \multicolumn{5}{|l|}{ Control for } \\
\hline Exchange characteristics & No & Yes & No & Yes \\
\hline Macroeconomic variables & No & Yes & No & Yes \\
\hline Technological integration dummy variables & Yes & Yes & Yes & Yes \\
\hline Difference in language and legal environment & Yes & Yes & Yes & Yes \\
\hline Country effect & Yes & Yes & Yes & Yes \\
\hline Year effect & Yes & Yes & Yes & Yes \\
\hline Adjusted R-squared & 0.24 & 0.41 & 0.17 & 0.34 \\
\hline No. of observations & 58 & 36 & 58 & 35 \\
\hline
\end{tabular}


Appendix A. Sample descriptions of M\&As and alliances

The following material provides a brief sample description of each of the types of cooperative agreements studied. The information for each description is taken directly from the news item used to identify the announcement of the events.

\section{A.1. M\&As}

At the NYSE Group's first meeting as a public company, the chief executive, John A. Thain, complained that the United States was losing lucrative stock listings to markets overseas because of the Sarbanes-Oxley Act. Of the largest 25 initial public offerings last year, 23 did not list in the United States, he said. This year, 9 of the 10 largest offerings went elsewhere. "That is a very negative statistic for the competitive position of the United States", Mr. Thain said.

After a whirlwind weekend of trans-Atlantic travel, Mr. Thain sealed a deal for the NYSE Group to buy Euronext, the pan-European stock and derivatives exchange, for $\$ 10.2$ billion, forming the first trans-Atlantic marketplace. Euronext, which was formed from mergers of the Paris, Amsterdam and Brussels stock exchanges, as well as the London derivatives exchange Liffe, will become part of NYSE Euronext, the American holding company that will be created. Regulators from each country where stocks trade will continue to oversee that activity. (The New York Times, June 2, 2006)

\section{A.2. Equity alliances (joint ventures)}

The American Stock Exchange, the global leader and pioneer in exchange-traded funds (ETFs) and Euronext, the first pan-European exchange, signed a memorandum of understanding to create a joint venture, subject to regulatory approval, to cross list and 
trade US, European and other internationally sourced ETFs. The joint venture will be a part of a global network of ETF marketplaces aiming at offering the best facilities for trading, cross listing, information dissemination, and marketing of the products globally. Ultimately the partners hope to achieve seamless 24-hour global trading of ETFs.

"Bringing Amex-listed ETFs to Europe, a critical market, is the essential next step in our strategy to develop a global ETF trading network", said Salvatore F. Sodano, Amex chairman and chief executive officer. "The Amex-Euronext alliance is truly revolutionary, as it aims to provide investors with the opportunity to trade the same class of ETF shares across time zones." (American Stock Exchange Official Website, February $7,2001)$

\section{A.3. Non-equity alliances (simple contracts)}

In a deal that allies the two biggest stock markets in the world, the NYSE Group, parent of the New York Stock Exchange, confirmed that it had signed a letter of intent to form a strategic alliance with the Tokyo Stock Exchange. The alliance calls for cooperation on joint listings, trading technology and marketing, with the possibility of investing in each other in the future. The exchange's non-exclusive alliance with Tokyo loosely defined and less substantive than its merger with Euronext or its ownership stake in India's national stock exchange - is an agreement to work together, the chief executives from the two exchanges said. Working groups are in place to examine possible linkages in areas like trading technology, cross-listings, new products including exchange-traded funds and areas of corporate governance and regulation. (The New York Times, February 1, 2007) 


\section{Appendix B. Brief descriptions of all the variables and their sources}

\begin{tabular}{|c|c|}
\hline Variables & Description \\
\hline \multicolumn{2}{|l|}{ Exchange performance measures } \\
\hline $\operatorname{CAR}[-1,1]$ & $\begin{array}{l}\text { Three-day cumulative abnormal return (in percentage } \\
\text { points) calculated using the extended market model. The } \\
\text { extended market model parameters are estimated over } \\
\text { the period }(-150,-31)\end{array}$ \\
\hline $\mathrm{BHAR}_{1,36}$ & $\begin{array}{l}\text { Three-year buy-and-hold abnormal return (in percentage } \\
\text { points). The benchmark is the value-weighted exchange } \\
\text { industry return }\end{array}$ \\
\hline Industry-adjusted ROE & $\begin{array}{l}\text { ROE minus asset-weighted industry ROE (in percentage } \\
\text { points) }\end{array}$ \\
\hline Industry-adjusted ROA & $\begin{array}{l}\text { ROA minus asset-weighted industry ROA (in percentage } \\
\text { points) }\end{array}$ \\
\hline Exchange liquidity & $\begin{array}{l}\text { Value of share trading divided by market capitalization } \\
\text { of listed stocks }\end{array}$ \\
\hline Industry-adjusted exchange liquidity & $\begin{array}{l}\text { Exchange liquidity minus asset-weighted industry } \\
\text { exchange liquidity }\end{array}$ \\
\hline Exchange IPO & $\begin{array}{l}\text { Market capitalization of IPOs divided by market } \\
\text { capitalization of listed stocks }\end{array}$ \\
\hline Industry-adjusted exchange IPO & $\begin{array}{l}\text { Exchange IPO minus asset-weighted industry exchange } \\
\text { IPO }\end{array}$ \\
\hline \multicolumn{2}{|l|}{ Deal characteristics } \\
\hline InterType & $\begin{array}{l}\text { It is equal to } 0 \text { when the deal is an M\&A, } 1 \text { when the } \\
\text { deal is a joint venture, and } 2 \text { when the deal is a non- } \\
\text { equity alliance }\end{array}$ \\
\hline Horizontal & $\begin{array}{l}\text { It equals } 1 \text { when the deal is a horizontal transaction, } \\
\text { otherwise } 0\end{array}$ \\
\hline CrossBorder & $\begin{array}{l}\text { It is equal to } 1 \text { when the deal is a cross-border } \\
\text { transaction, otherwise } 0\end{array}$ \\
\hline TechnologicalIntegration & $\begin{array}{l}\text { Dummy variables to indicate the type of technological } \\
\text { integration (outsourcing, common access, common } \\
\text { systems, common operations, complete system } \\
\text { integration, and other type of integration) }\end{array}$ \\
\hline Public & $\begin{array}{l}\text { It is equal to } 1 \text { when the target exchange is a publicly } \\
\text { traded exchange in an M\&A or the partner is a publicly } \\
\text { traded exchange in a joint venture (non-equity alliance), } \\
\text { otherwise } 0\end{array}$ \\
\hline \multicolumn{2}{|l|}{ Learning-by-doing variables } \\
\hline NoPreMA & $\begin{array}{l}\text { The number of previous M\&A events experienced by a } \\
\text { given exchange }\end{array}$ \\
\hline NoPreJV & $\begin{array}{l}\text { The number of previous joint venture events } \\
\text { experienced by a given exchange }\end{array}$ \\
\hline NoPreAL & $\begin{array}{l}\text { The number of previous non-equity alliance events } \\
\text { experienced by a given exchange }\end{array}$ \\
\hline \multicolumn{2}{|l|}{ Exchange characteristics } \\
\hline MarketValue & $\begin{array}{l}\text { Market value on the } 31 \text { st trading day prior to } \\
\text { announcement date }\end{array}$ \\
\hline TotalAssets & Total assets \\
\hline CashFlow & $\begin{array}{l}\text { Operating income before depreciation - interest } \\
\text { expenses - income taxes - capital } \\
\text { expenditures, scaled by total assets }\end{array}$ \\
\hline Leverage & Total liabilities scaled by total assets \\
\hline $\mathrm{Q}$ & Market value of assets over book value of assets \\
\hline \multicolumn{2}{|l|}{ Macroeconomic development variables } \\
\hline GDPPerCapita & GDP per capita \\
\hline GDPGrowth & GDP growth \\
\hline $\begin{array}{l}\text { Difference in language and legal } \\
\text { environment }\end{array}$ & \\
\hline
\end{tabular}




\begin{tabular}{ll}
\hline SameLanguage, & $\begin{array}{l}\text { It equals one when two partnering stock exchanges' } \\
\text { countries share the same language and zero otherwise }\end{array}$ \\
\hline SameLegalSystem, & $\begin{array}{l}\text { It equals one when two partnering stock exchanges' } \\
\text { countries share the same legal origin and zero otherwise }\end{array}$ \\
\hline Difference in capital market development & $\begin{array}{l}\text { The difference in the market capitalization of listed } \\
\text { stock scaled by GDP between the partner stock } \\
\text { exchange' country and the sample stock exchange's } \\
\text { country }\end{array}$ \\
\hline DifTurnover & $\begin{array}{l}\text { The difference in the stock traded turnover ratio between } \\
\text { the partner stock exchange' country and the sample } \\
\text { stock exchange's country }\end{array}$ \\
\hline DifStockTradeToGDP & $\begin{array}{l}\text { The difference in the total value of stock traded scaled } \\
\text { by GDP between the partner stock exchange' country } \\
\text { and the sample stock exchange's country }\end{array}$ \\
\hline Difference in governance & $\begin{array}{l}\text { The difference in the shareholder protection index (the } \\
\text { product of the shareholder rights index and the } \\
\text { efficiency of the legal system) between the partner stock } \\
\text { exchange' country and the sample stock exchange's } \\
\text { country }\end{array}$ \\
\hline DifShareHolderProtection & $\begin{array}{l}\text { The difference in accounting standard index between the } \\
\text { partner stock exchange' country and the sample stock } \\
\text { exchange's country }\end{array}$ \\
\hline
\end{tabular}


